\title{
Article \\ Molecular Characterization of TRPA Subfamily Genes and Function in Temperature Preference in Tuta absoluta (Meyrick) (Lepidoptera: Gelechiidae)
}

\author{
Xiao-Di Wang ${ }^{1}$, Ze-Kai Lin ${ }^{1}{ }^{\circledR}$, Shun-Xia Ji ${ }^{1}$, Si-Yan Bi ${ }^{1}$, Wan-Xue Liu ${ }^{1}$, Gui-Fen Zhang ${ }^{1}$, Fang-Hao Wan ${ }^{1,2}$ \\ and Zhi-Chuang $L \ddot{u}^{1, *}$ \\ 1 State Key Laboratory for Biology of Plant Diseases and Insect Pests, Institute of Plant Protection, \\ Chinese Academy of Agricultural Sciences, Beijing 100193, China; 82101195160@caas.cn (X.-D.W.); \\ lincsaurora@gmail.com (Z.-K.L.); 82101172334@caas.cn (S.-X.J.); bisiyan91@gmail.com (S.-Y.B.); \\ liuwanxue@caas.cn (W.-X.L.); zhangguifen@caas.cn (G.-F.Z.); wanfanghao@caas.cn (F.-H.W.) \\ 2 Agricultural Genome Institute at Shenzhen, Chinese Academy of Agricultural Sciences, \\ Shenzhen 518120, China \\ * Correspondence: lvzhichuang@caas.cn; Tel.: +86-10-8210-9572
}

\section{check for}

updates

Citation: Wang, X.-D.; Lin, Z.-K.; Ji, S.-X.; Bi, S.-Y.; Liu, W.-X.; Zhang, G.-F.; Wan, F.-H.; Lü, Z.-C. Molecular Characterization of TRPA Subfamily Genes and Function in Temperature Preference in Tuta absoluta (Meyrick) (Lepidoptera: Gelechiidae). Int. J. Mol. Sci. 2021, 22, 7157. https://doi.org/ $10.3390 /$ ijms 22137157

Academic Editor: Henryk Hanokh Czosnek

Received: 18 May 2021

Accepted: 29 June 2021

Published: 2 July 2021

Publisher's Note: MDPI stays neutral with regard to jurisdictional claims in published maps and institutional affiliations.

Copyright: (c) 2021 by the authors. Licensee MDPI, Basel, Switzerland. This article is an open access article distributed under the terms and conditions of the Creative Commons Attribution (CC BY) license (https:// creativecommons.org/licenses/by/ $4.0 /)$.

\begin{abstract}
To reveal the mechanism of temperature preference in Tuta absoluta, one of the top 20 plant pests in the world, we cloned and identified TaTRPA1, TaPain, and TaPyx genes by RACE and bioinformatic analysis, and clarified their expression profiles during different development stages using real-time PCR, and revealed their function in preference temperature by RNAi. The full-length cDNA of TaPain was 3136 bp, with a 2865-bp open reading frame encoding a 259.89-kDa protein; and the partial length cDNA of TaPyx was 2326-bp, with a 2025-bp open reading frame encoding a 193.16-kDa protein. In addition, the expression of TaTRPA1 and TaPyx was significantly lower in larvae than other stages, and it was significantly higher in pupae and newly emerging males for TaPain. After feeding target double-stranded RNA (dsRNA), the preferred temperature decreased $2{ }^{\circ} \mathrm{C}$ more than the control group. In conclusion, the results firstly indicated the molecular characterization of TRPA subfamily genes and their key role in temperature perception in T. absoluta, and the study will help us to understand the temperature-sensing mechanism in the pest, and will provide some basis for study of other Lepidoptera insects' temperature preference. Moreover, it is of great significance in enriching the research progress of "thermos TRP".
\end{abstract}

Keywords: Tuta absoluta; TRPA1; Painless; Pyrexia; RNA interference; temperature preference

\section{Introduction}

The South American tomato leaf miner, Tuta absoluta (Meyrick) (Lepidoptera: Gelechiidae) originated in South America, and has been one of the worst pests in South America since the 1950s and can reduce crop yields by $80-100 \%$ [1-3]. It threatens crops in the nightshade family such as tomatoes, potatoes, eggplant, peppers, and tobacco $[4,5]$. T. absoluta mainly damages in the larval stage, and can do harm in any development stage and any above-ground part of the tomato plant. Since its accidental introduction to Spain in 2006, the pest has rapidly invaded many countries and regions, posing a serious threat to the global tomato production [2,6-10]. T. absoluta was reported in Israel in 2009, then spread steadily in 15 western Asian countries between 2010 and 2015, and has been found in several countries in southern, central, and eastern Asia in recent years. It can be seen that its invasion range is wide, and the invasion speed is fast [5]. The invasive species was firstly discovered in August 2017 in Huocheng County, Ili Kazakg Autonomous Prefecture, Xinjiang Uygur Autonomous Region (Huocheng, Ili, Xinjiang), China. The successful invasion of the pest has posed a great threat to the tomato industry in Xinjiang and other places [5]. So, it is particularly important and urgent to study its invasion mechanism. As 
an important parameter affecting population growth and development, temperature is closely related to successful invasion and colonization.

Temperature is an important factor limiting the adaptive distribution of species and determines the distribution and diffusion area of species. Insects are very sensitive to temperature changes [11,12]. In fact, temperature is one of the key abiotic factors that directly affects insect reproduction, development, activity, adaptation, survival, and spatio-temporal distribution $[13,14]$. In nature, insects are faced with multiple environmental pressures, which may seriously affect their survival. In order to adapt to the environment, insects can adopt a set of mechanisms on the acute and chronic timescales, so as to improve the adaptability in the suboptimal environment. Including T. absoluta, there was some research about the behavioral observations under different temperature environments [15-17], and the underlying molecular mechanism has not been declared. Li et al. [15] reported that that temperature affected the growth, development, and reproduction of T. absoluta. The developmental duration of $T$. absoluta was shortened with the increase in temperature in the range of $15-30{ }^{\circ} \mathrm{C}$. The survival rate of the larval and the early adult, and the total egg production of the female moth reached the maximum at $25^{\circ} \mathrm{C}$. In addition, both the adults and the larvae of T. absoluta were chill susceptible and successfully overwintered in warm African environments. However, studies have shown that larvae are more resistant to cold than adults, which may be due to the advantages of the physiological adaptation and ecological factors of larvae [17]. Furthermore, Tarusikirwa et al. [16] revealed that the thermal plasticity of T. absoluta larvae is stronger than that of adults, and they can change their thermal tolerance in a short time and long timescales.

Body temperature $(\mathrm{Tb})$ plays a key role in the performance of ectotherms [18-21], which regulate body temperature through behavioral responses in order to achieve the appropriate temperature conditions [22-24]. When presented with a choice of ambient temperatures, as in a thermal gradient, motile organisms tend to congregate in, or spend the most time in, a relatively narrow range of temperatures. Such behavior is termed temperature preference or behavioral thermoregulation [25-28]. At present, for more than 50 species of terrestrial invertebrates, researchers have measured the preferred temperature (Tpref), which is closely related to the ecological process from individual behavior to population and community dynamics as an indicator of behavioral temperature regulation in a variable environment [29-32]. In addition, the preferred temperature can be measured by a thermal gradient $[19,26-28]$. Insects, as small ectotherms, are very sensitive to temperature perception, and Tpref reflects the individual's choice of the most favorable thermal microhabitat, which is related to increasing foraging opportunities and avoiding predators [33-35]. Quantifying the Tpref of individuals is, therefore, important in understanding how thermal landscapes mechanistically contribute to shaping the distributions of species via behavioral thermoregulation [29].

Transient receptor potential channels, also known as TRP channels, are a superfamily of ion channels occurring on cell membranes and are related to various sensory receptions, including thermal receptivity, chemical receptivity, mechanical receptivity, and light receptivity [36]. The channel was firstly identified in the late 1970s and early 1980s in the light-sensing cells of fruit flies [37]. Since then, these channels have been found in a variety of organisms from worms to flies and humans $[38,39]$. According to the similarity of gene sequences and protein structures, these channels have been divided into seven families, namely TRPC, TRPV, TRPA, TRPN, TRPM, TRPML, and TRPP [40,41]. These channels are located on the outer membranes of different types of sensory cells and respond to various stimuli by regulating the flow of potassium, calcium, and sodium plasma in and out of the cells [36]. Mammalian TRPV is a classical "thermoTRP", which can be directly activated at temperatures greater than or equal to $42^{\circ} \mathrm{C}$ [42]. Drosophila larvae and adults also use thermoTRPs to avoid harmful cold and heat, and to identify minute temperature differences within a comfortable range $\left(18-24^{\circ} \mathrm{C}\right)[36]$, and use the "thermoTRP" mechanism to identify the comfort zone. The noxious response is a necessary condition for animals to respond quickly to potentially fatal sensory attacks. There are at least three TRP channels 
in the adult Drosophila melanogaster that contribute to the timely response to overheating injury, namely TRPA1, Pyrexia (Pyx), and Painless (Pain), all of which belong to the TRPA subfamily $[43,44]$. When subjected to a harmful temperature $\left(>39^{\circ} \mathrm{C}\right)$ or strong mechanical stimulation, larvae made an evasive response dependent on mdIV neurons and TRPA1 and Painless (Pain) channels [44-47]. Pain has a temperature activation threshold of $39-42{ }^{\circ} \mathrm{C}$ and is expressed in mdIV neurons [45,48]. The Pyx channel is directly activated by high temperatures close to $40^{\circ} \mathrm{C}$, and, when exposed to $40^{\circ} \mathrm{C}$, a mutation in fever leads to faster paralysis [43]. The results show that TRP protein can be activated by specific temperature changes, so that neurons can convey temperature information and play the role of molecular thermometers in insects [49,50]. In the study of two cryptic species of Bemisia tabaci AsiaII3 and MEAM1 (Middle East Asia Minor 1), it was found that temperature stress could induce the expression of $B t T R P$ mRNA, and played an important role in heat tolerance. According to this characteristic, researchers infer that BtTRP also belongs to the TRPA subfamily [51-53]. Therefore, the TRPA subfamily plays an important role in temperature sensing and the heat escape injury response.

To assess the preferred temperature sensation mechanism of the TRPA genes in T. absoluta, the following aspects were explored. First, we cloned partial or full-length cDNA sequences of the TRPA genes and analyzed the characteristics of these genes. Second, we examined the mRNA expression profiles of the TaTRPA1, TaPain, TaPyx genes during different developmental stages by quantitative real-time PCR. Third, we identified the function of the TRPA genes in the selection preference temperature using the feeding dsRNA method. Our findings can provide a theoretical basis for further study on the mechanisms of adaptation to environmental temperatures of T. absoluta.

\section{Results}

2.1. Cloning of TaPain and TaPyx

The full-length cDNA of T. absoluta TaPain is $3136 \mathrm{bp}$ and contains a 71-bp $5^{\prime}$-untranslated region (5'-UTR) (positions 1-71), a 200-bp 3'-UTR (positions 2937-3136), and a 2865-bp open reading frame (ORF) (positions 72-2936). The ORF encodes a polypeptide of 954 amino acids with a calculated molecular mass of $259.89 \mathrm{kDa}$ and an isoelectric point (pI) of 4.86 (Figure 1A). The accession numbers of TaPain are MZ382839.

The partial length cDNA of T. absoluta TaPyx is 2326 bp and contains a 177-bp $5^{\prime}$-untranslated region (5'-UTR) (positions 1-177), a 124-bp 3'-UTR (positions 2203-2326), and a 2025-bp open reading frame (ORF) (positions 178-2202). The ORF encodes a polypeptide of 674 amino acids with a calculated molecular mass of $193.16 \mathrm{kDa}$ and an isoelectric point (pI) of 4.92 (Figure 1B). The accession numbers of TaPyx genes are MZ382840.

\subsection{Sequence Analysis of TaTRPA1, TaPain, and TaPyx}

The transmembrane helices in the TRPA protein were predicted by using the online software Phobius (https://phobius.sbc.su.se/. Accessed on 20 April 2021). As shown in Figure 2A, eight ankyrin repeats were found in T. absoluta Painless; the amino acid positions of ANK1-ANK8 were as follows: 59-89, 94-124, 127-169, 173-203, 278-307, 312-341, 344-386, 390-419, and six transmembrane structures (TM1-TM6) were found in T. absoluta TaPain, and the amino acid positions of 535-558, 570-588, 608-626, 633-653, 673-692, 754-775 indicated the transmembrane structure positions of TM1, TM2, TM3, TM4, TM5, and TM6, respectively. There are six transmembrane structures in T. absoluta TaPyx (Figure 2B). The amino acid positions of TM1-TM6 were as follows: 252-275, 314-332, 353-373, 379-404, 416-436, 483-505. 


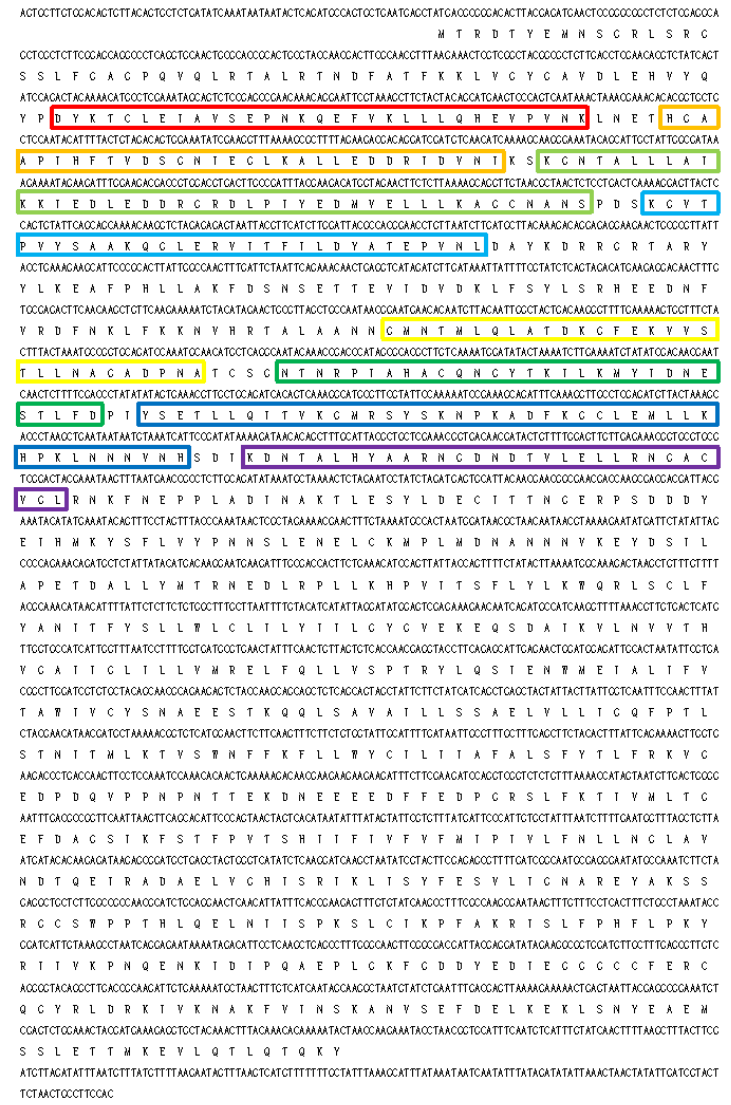

(A)

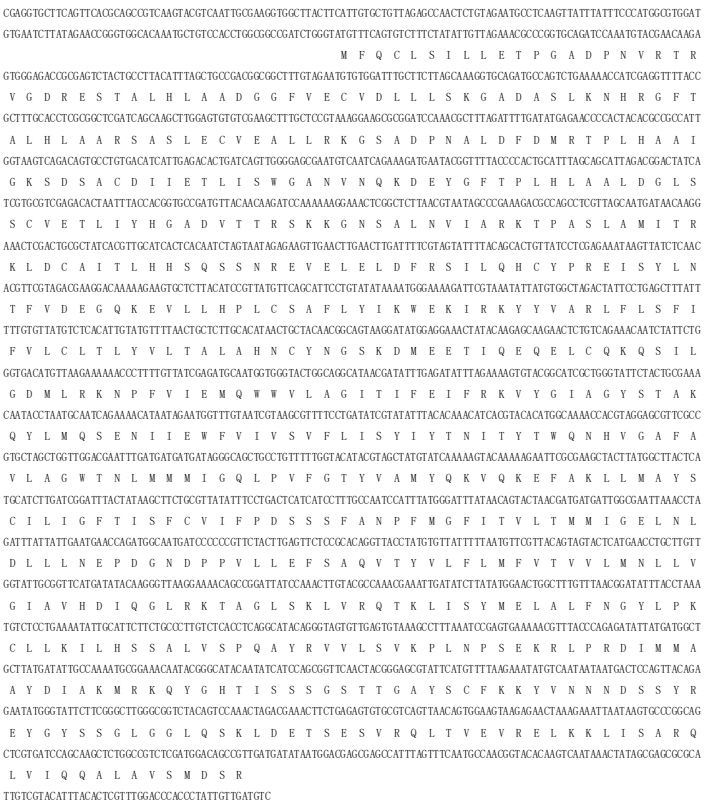

(B)

Figure 1. (A). Full-length cDNA sequence of Tuta absoluta TaPain and its deduced amino acid sequence. The full-length cDNA of T. absoluta TaPain is $3136 \mathrm{bp}$, and the open reading frame (72-2936 bp) encodes a polypeptide of 954 amino acids. Eight boxes in different colors are marked with eight ankyrin repeats. (B). Partial length cDNA sequence of Tuta absoluta TaPyx and its deduced amino acid sequence. The partial length cDNA of T. absoluta TaPyx is $2326 \mathrm{bp}$, and the open reading frame 178-2202 bp encodes a polypeptide of 674 amino acids. 


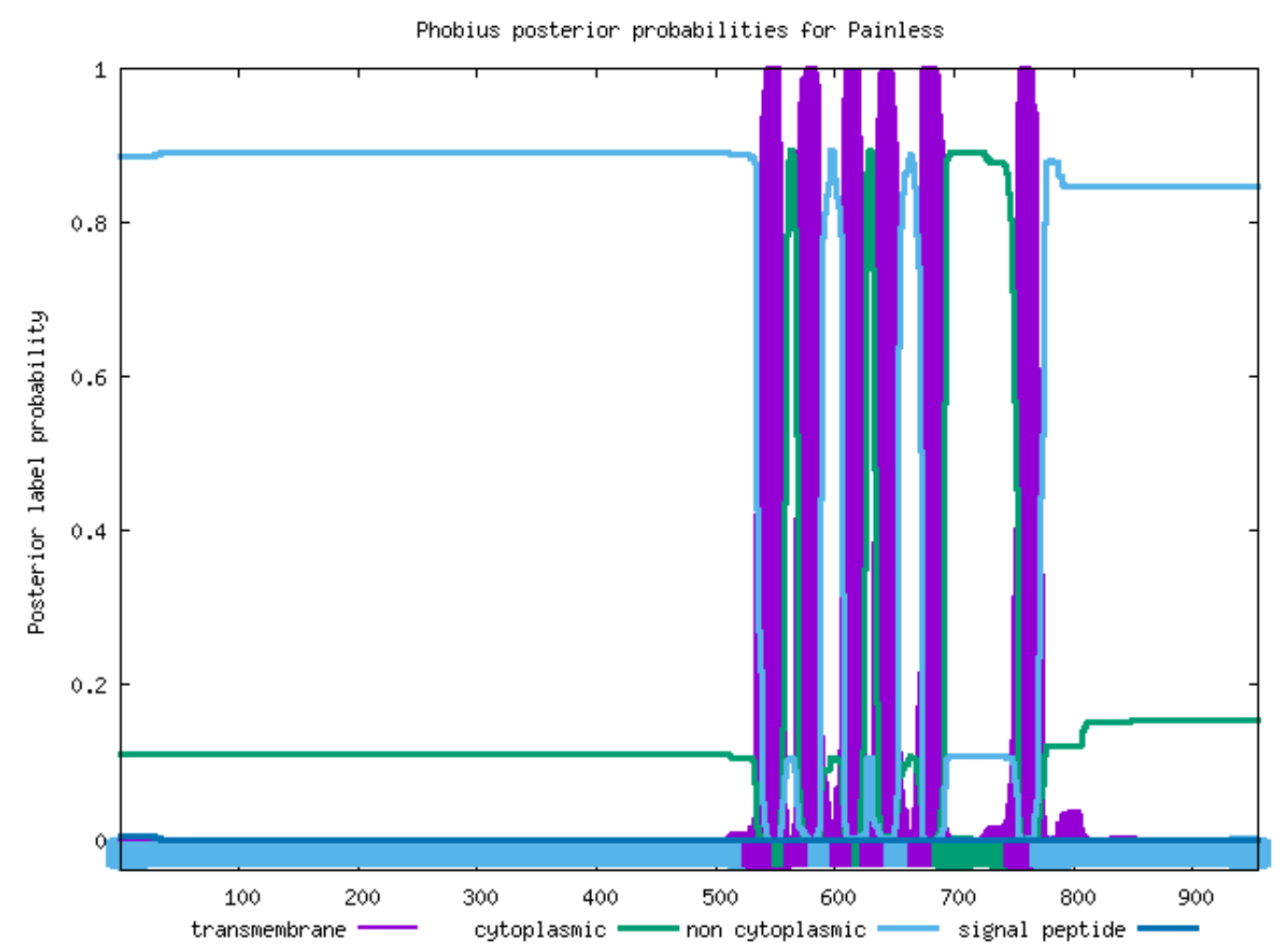

(A)

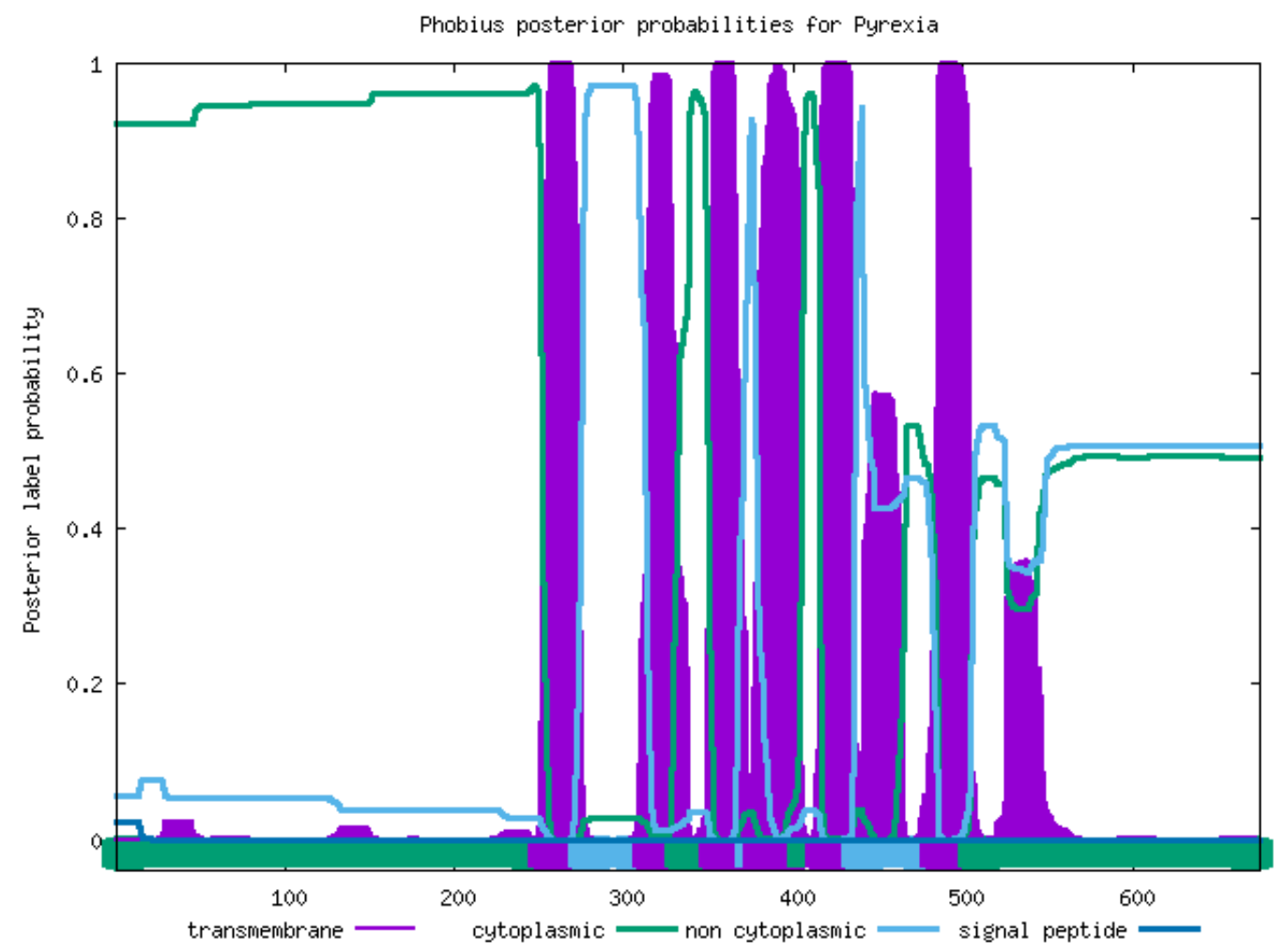

(B)

Figure 2. (A). Transmembrane structure prediction of the TaPain protein in Tuta absoluta. Six transmembrane structures were found in Tuta absoluta TaPain. The transmembrane structural positions of TM1, TM2, TM3, TM4, TM5, and TM6 were located at the amino acid positions of 535-558, 570-588, 608-626, 633-653, 673-692, and 754-775, respectively. (B). Transmembrane structure prediction of the TaPyx protein in Tuta absoluta. Six transmembrane structures were found in Tuta absoluta TaPyx. The transmembrane structural positions of TM1, TM2, TM3, TM4, TM5, and TM6 was located at the amino acid positions of 252-275, 314-332, 353-373, 379-404, 416-436, and 483-505, respectively. 
We also used Swiss-Model online software to predict the three-dimensional structures of Painless and Pyrexia, and found that they both contained six transmembrane domains, and found eight ankyrin repeats of Painless. It is helpful for us to understand the structural characteristics and functions of the protein through the three-dimensional structure of the protein. The specific spatial conformation formed by the folding of Painless and Pyrexia proteins allows us to see more visually the transmembrane domain and ankyrin repeats, as shown in Figure 3.

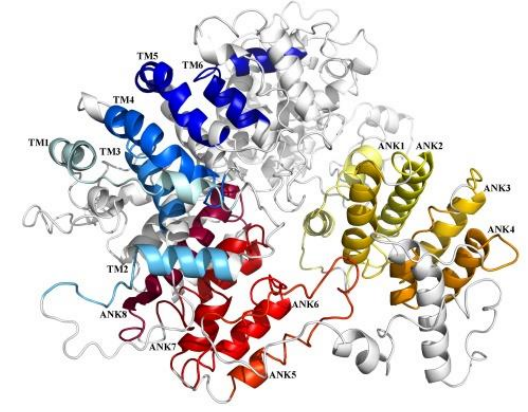

(A). The predicted Painless transmembrane domains structure and ankyrin repeats

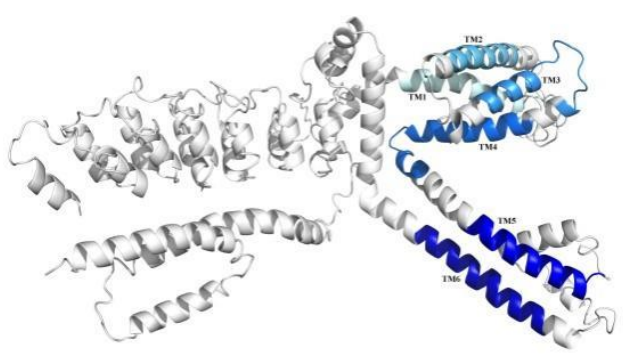

(B). The predicted Pyrexia transmembrane domains structure

Figure 3. The conserved domains of Painless and Pyrexia in Tuta absoluta. The light blue to dark blue represent different transmembrane domains structure, and the light yellow to red represent different ankyrin repeats.

A blastx program showed that T. absoluta Painless shared more than $73 \%$ identity with previously identified Painless proteins from other Lepidoptera (Bombyx mandarina XP_028039162.1; Bombyx mori NP_001296553.1; Danaus plexippus plexippus XP_032511715.1; Helicoverpa armigera XP_021191851.1; Zerene cesonia XP_038213738.1; Trichoplusia ni XP_ 026747274.1; Spodoptera litura XP_022826996.1; Pararge aegeria XP_039745767.1; Operophtera brumata KOB66914.1; Papilio Xuthus KPJ01914.1; Vanessa tameamea XP_026491621.1; Ostrinia furnacalis XP_028177403.1; Heliconius Melpomene QDR50965.1; Pieris rapae XP_022120653.1; Manduca sexta XP_030023596.2; Plutella xylostella XP_011560772.2.). We directly compared the amplified TaTRPA1 nucleotide sequence to blastx sequences in NCBI, and it was found that the identity with known TRPA1 sequences among 26 species, such as M. Sexta and Spodoptera frugiperda, exceeded $75 \%$. The identity of TaPyx with known Pyx sequences among 43 species, such as B. mori and H. armigera, was over $70 \%$. We selected six representative species for multiple sequence alignment, and found that the identity of the Painless protein was up to $84.57 \%$, and that of the Pyrexia protein was up to $89.78 \%$. Although TRPA1 only amplified part of the sequences, the identity between the amplified sequences and the other five species was $70.96 \%$. The results of multiple sequence alignment are shown in Figure $4 \mathrm{~A}-\mathrm{C}$, which indicated that these three genes were all relatively conserved.

The phylogenetic tree was constructed using the maximum likelihood method with 1000 bootstrap replications in MEGA 7.0 software. By constructing phylogenetic tree analysis, the evolutionary history of these genes can be easily understood. Insects of the same order gather in the same branch, indicating that these genes are relatively conserved during the whole evolutionary process. The phylogenetic tree revealed that the TRPA1 (green region), Painless (blue region), and Pyrexia (red region) proteins of insects clustered on a single branch in each order, and eventually all the three proteins clustered on the same branch (Figure 5). In addition, it could be seen that the TRPA1 of T. absoluta and the Lepidoptera such as O. furnacalis, P. xuthus, Papilio machaon, B. mori, and B. mandarina clustered in the same branch. The Painless of T. absoluta and the Lepidoptera such as P. xylostella, O. furnacalis, T. ni, and H. armigera clustered in the same branch. The Pyrexia of T. absoluta and the Lepidoptera such as H. armigera, T. ni, Galleria mellonella, and $O$. furnacalis clustered in the same branch. The above results showed that that these genes are conserved throughout evolution, which is consistent with the traditional taxonomy. 


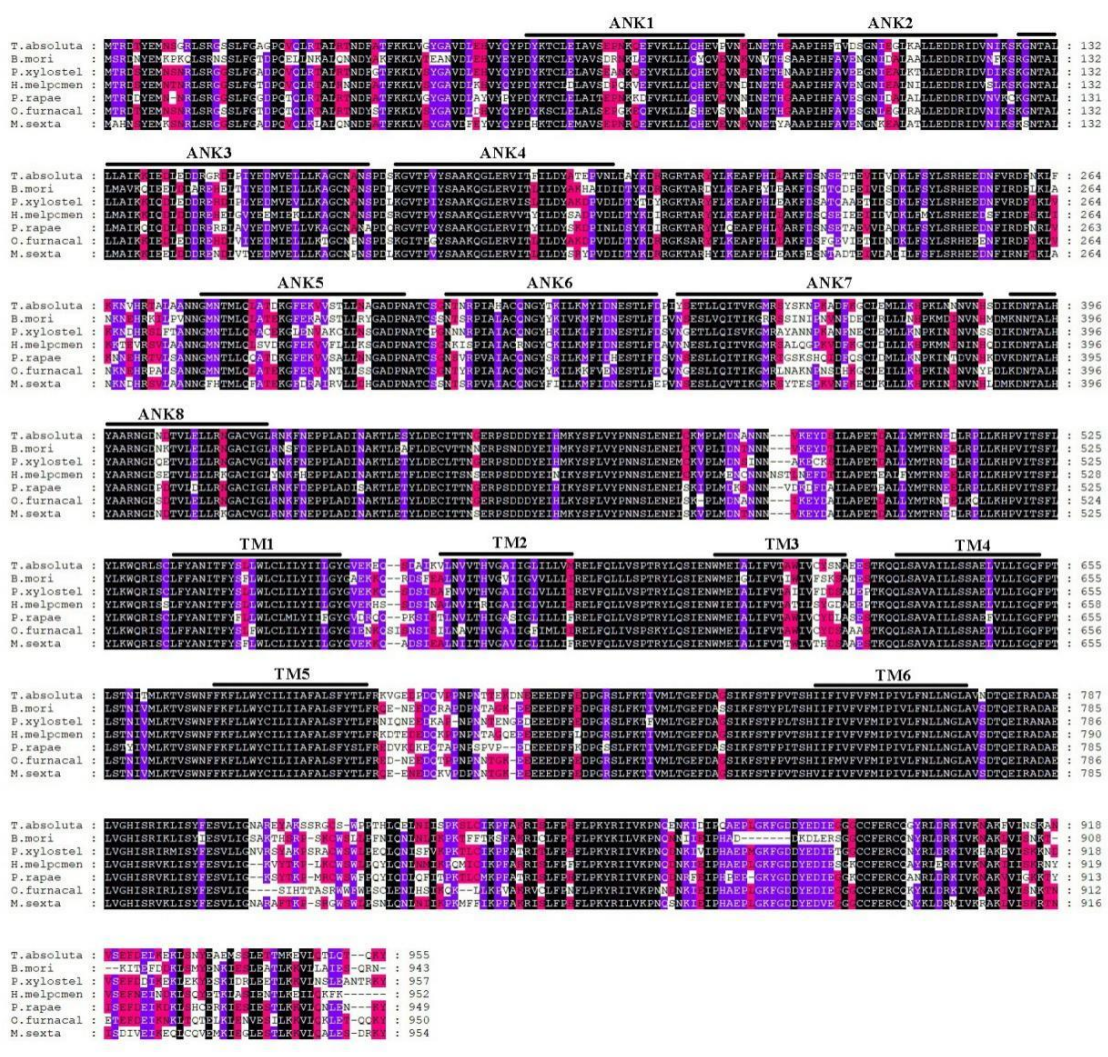

(A)

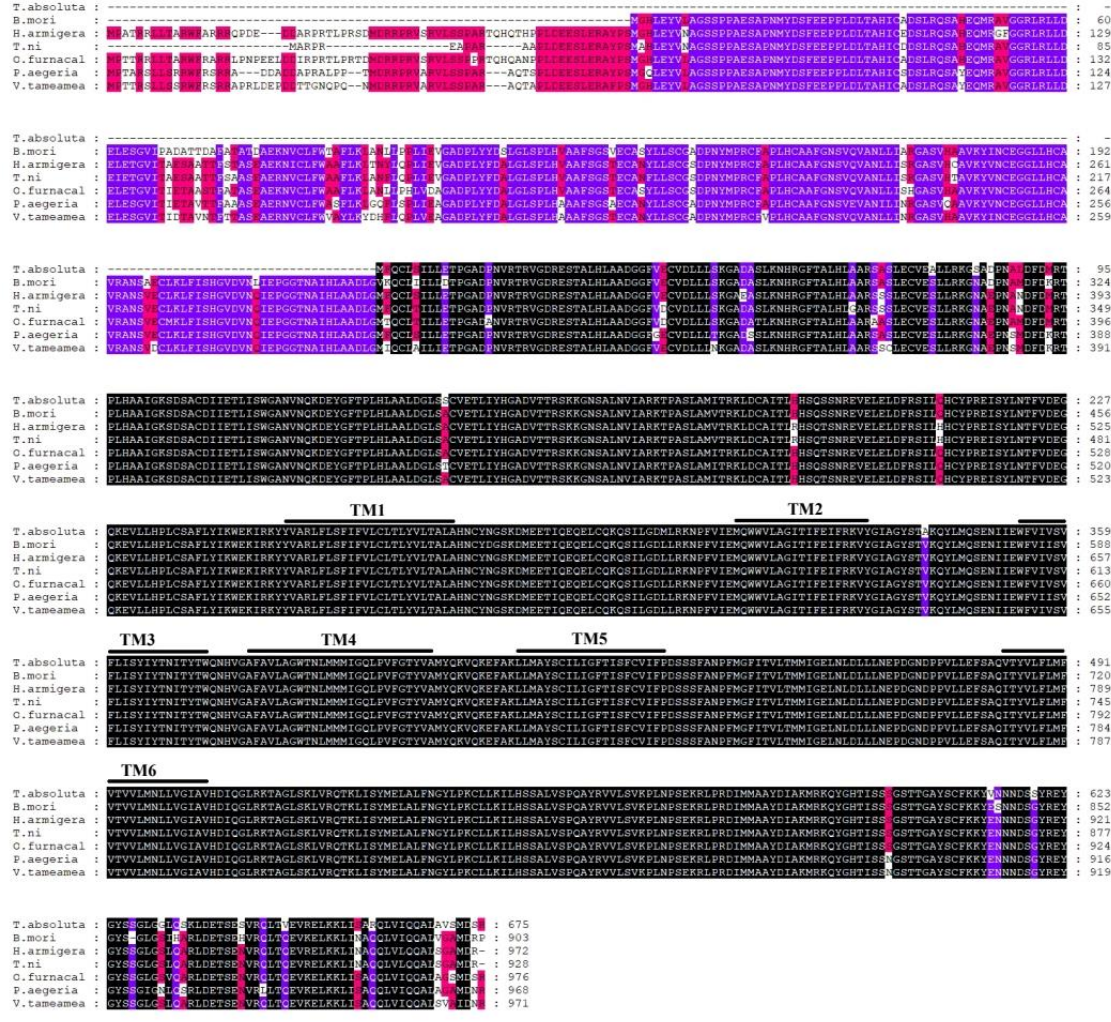

(B)

Figure 4. Cont. 


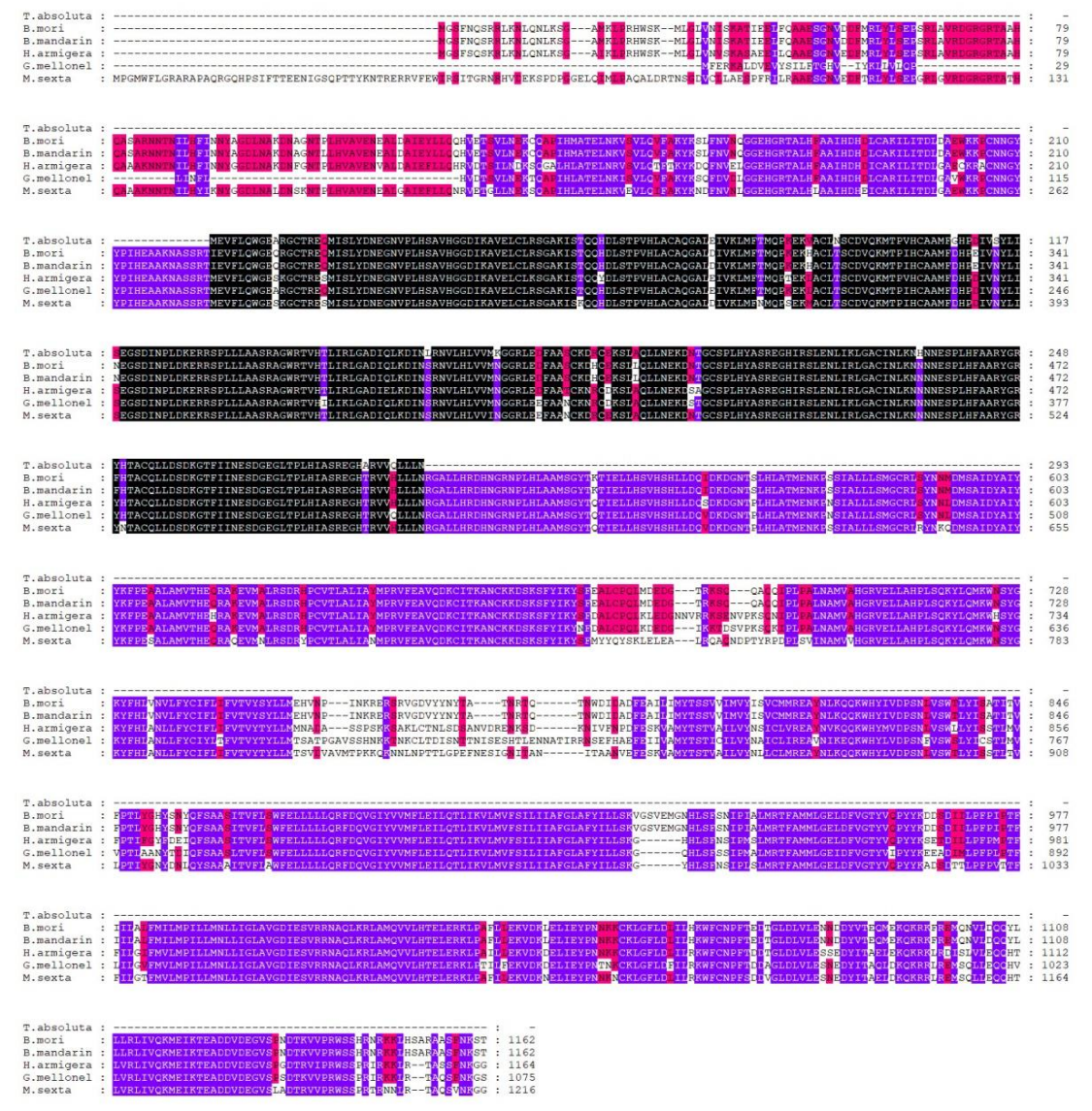

(C)

Figure 4. (A). Alignment of TRP protein from Tuta absoluta and other insects. Black represents that the amino acid sequences of seven species in multiple sequence alignment are completely identical; purple represents that six species out of seven species have the same amino acid sequences at this site; red represents that four to five species out of seven species have the same amino acid sequences at this site; and no color represents that there are differences among species. B. mori: Bombyx mori Painless (001296553.1); P. xylostella: Plutella xylostella Painless (XP_011560772.2); H. Melpomene: Heliconius Melpomene Painless (QDR50965.1); P. rapae: Pieris rapae Painless (XP_022120653.1); O. furnacalis: Ostrinia furnacalis Painless (XP_028177403.1); M. sexta: Manduca sexta Painless (XP_030023596.2). (B). Alignment of Pyrexia protein from Tuta absoluta and other insects. Black represents that the amino acid sequences of seven species in multiple sequence alignment are completely identical; purple represents that six species out of seven species have the same amino acid sequences at this site; red represents that four to five species out of seven species have the same amino acid sequences at this site; and no color represents that there are differences among species. B. mori: Bombyx mori Pyrexia (NP_001296553.1); H. armigera: Helicoverpa armigera Pyrexia (XP_021194189.1); T. ni: Trichoplusia Pyrexia ni(XP_026735810.1); O. furnacalis: Ostrinia furnacalis Pyrexia (XP_028163008.1); P. aegeria: Pararge aegeria Pyrexia (XP_039759808.1); V. tameamea: Vanessa tameamea Pyrexia (XP_026483194.1). (C). Alignment of TRPA1 protein from Tuta absoluta and other insects. Black represents that the amino acid sequences of six species in multiple sequence alignment are completely identical; purple represents that five species out of six species have the same amino acid sequences at this site; red represents that four species out of six species have the same amino acid sequences at this site; and no color represents that there are differences among species. B. mori: Bombyx mori TRPA1 (NP_001296525.1); B. mandarina: Bombyx mandarina TRPA1(XP_028033887.1); H. armigera: Helicoverpa armigera TRPA1(XP_021185779.1); G. mellonella: Galleria mellonella TRPA1(XP_031767554.1); M. sexta: Manduca sexta TRPA1(XP_037299698.1). 


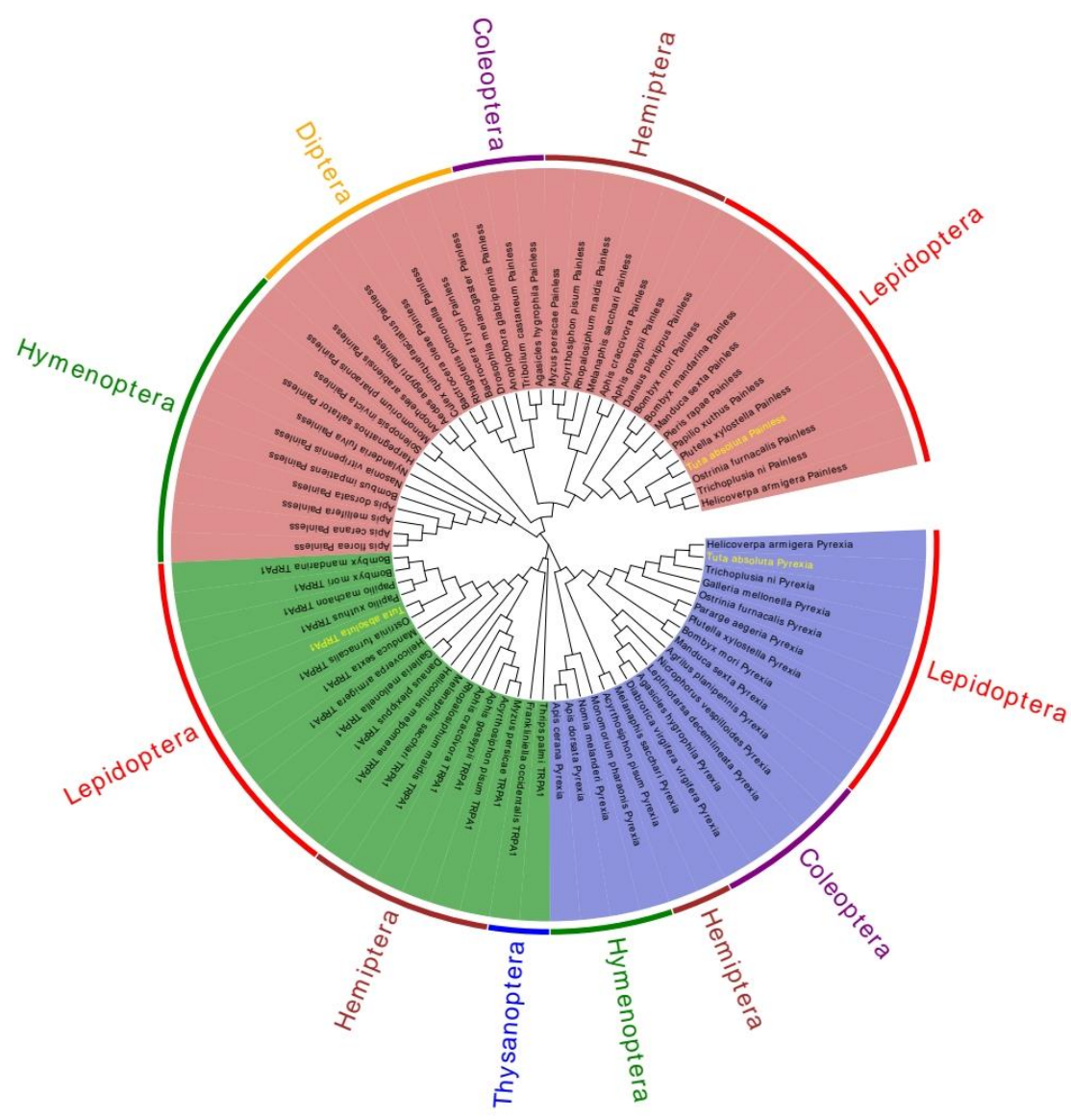

Figure 5. A phylogenetic tree based on the known amino acid sequences of TRPA genes. The phylogenetic tree was generated via Maximum Likelihood method based on the poisson correction mode, and this tree was used to determine the relationships between different insects. Helicoverpa armigera Pyrexia (XP_021194189.1); Trichoplusia ni Pyrexia (XP_026735810.1); Galleria mellonella Pyrexia (XP_026761448.2); Ostrinia furnacalis Pyrexia (XP_028163008.1); Pararge aegeria Pyrexia(XP_039759808.1); Plutella xylostella Pyrexia(XP_037962898.1); Bombyx mori Pyrexia (NP_001296536.1); Manduca sexta Pyrexia (XP_030021352.2); Agrilus planipennis Pyrexia (XP_018334781.1); Nicrophorus vespilloides Pyrexia (XP_017775114.1); Leptinotarsa decemlineata Pyrexia (XP_023020123.1); Agasicles hygrophila Pyrexia (QLH02045.1); Diabrotica virgifera virgifera Pyrexia (XP_028131629.1); Melanaphis sacchari Pyrexia (XP_025205608.1); Acyrthosiphon pisum Pyrexia (XP_016657902.1); Monomorium pharaonic Pyrexia (XP_012535072.2); Nomia melanderi Pyrexia (XP_031825641.1); Apis dorsata Pyrexia (XP_006623313.1); Apis cerana Pyrexia (XP_028522925.1); Thrips palmi TRPA1 (XP_034255303.1); Frankliniella occidentalis TRPA1 (XP_026285236.1); Myzus persicae TRPA1 (XP_022167295.1); Acyrthosiphon pisum TRPA1(XP_029342925.1); Aphis gossypii TRPA1 (XP_027848279.1); Aphis craccivora TRPA1 (KAF0770012.1); Rhopalosiphum maidis TRPA1 (XP_026809343.1); Melanaphis sacchari TRPA1 (XP_025200861.1); Heliconius melpomene TRPA1(QDR50963.1); Danaus plexippus TRPA1 (QDQ16924.1); Galleria mellonella TRPA1 (XP_031767554.1); Helicoverpa armigera TRPA1 (XP_021185779.1); Manduca sexta TRPA1 (QDR51038.1); Ostrinia furnacalis TRPA1 (XP_028170510.1); Papilio xuthus TRPA1 (KPJ00566.1); Papilio machaon TRPA1 (KPJ09099.1); Bombyx mori TRPA1 (NP_001296525.1); Bombyx mandarina TRPA1(XP_028033887.1); Apis florea Painless (XP_031772455.1); Apis cerana Painless (XP_028520736.1); Apis mellifera Painless(XP_006562517.1); Apis dorsata Painless (XP_031369976.1); Bombus impatiens Painless (XP_024223159.1); Nasonia vitripennis Painless (XP_031783731.1); Nylanderia fulva Painless (XP_029174885.1); Harpegnathos saltator Painless (XP_025162136.1); Solenopsis invicta Painless (XP_039303762.1); Monomorium pharaonis Painless (XP_036145416.1); Anopheles arabiensis Painless (XP_040153163.1); Aedes aegypti Painless (XP_001652261.2); Culex quinquefasciatus Painless (XP_001849122.2); Bactrocera oleae Painless (XP_036223549.1); Rhagoletis pomonella Painless(XP_036331109.1); Bactrocera tryoni Painless (XP_039969281.1); Drosophila melanogaster Painless(NP_611979.1); Anoplophora glabripennis Painless(XP_018573376.1); Tribolium castaneum Painless (NP_001164308.1); Agasicles hygrophila Painless (QLH02046.1); Myzus persicae Painless (XP_022174286.1); Acyrthosiphon pisum Painless (XP_029346868.1); Rhopalosiphum maidis Painless (XP_026806747.1); Melanaphis sacchari Painless (XP_025190493.1); Aphis craccivora Painless (KAF0773934.1); Aphis gossypii Painless (XP_027846115.1); Danaus plexippus Painless (QDQ16926.1); Bombyx mori Painless (NP_001296553.1); Bombyx mandarina Painless (XP_028039162.1); Manduca sexta Painless (XP_030023596.2); Pieris rapae Painless (XP_022120653.1); Papilio xuthus Painless (KPJ01914.1); Plutella xylostella Painless (XP_011560772.2); Ostrinia furnacalis Painless (XP_028177403.1); Trichoplusia ni Painless(XP_026747274.1); Helicoverpa armigera Painless (XP_021191852.1). 


\subsection{Expression Profiles of TaTRPA1, TaPain, and TaPyx during Different Developmental Stages}

Real-time PCR was used to isolate and amplify cDNA from eggs, nymphs from the first to fourth instars, early to late pupae, newly emerged to mature females and males. The results indicated that TaTRPA1, TaPain, and TaPyx expressed at all the developmental stages tested (Figure 6). The expression level of TaTRPA1 in the pupal stage $(39.81 \pm 4.04, d f=4$, $p<0.05)$ and newly emergence stage $(29.17 \pm 5.23, d f=4, p<0.05)$ was significantly higher than that in other stages. The expression levels of Painless and Pyrexia in the pupal stage $(7.48 \pm 1.20, d f=4, p<0.05 ; 41.96 \pm 10.60, d f=4, p<0.05)$ and incipient emerging males $(5.04 \pm 0.80, d f=4, p<0.05 ; 25.80 \pm 7.47, d f=4, p<0.05)$ were significantly higher than those in other developmental stages. Through gene expression profile analysis, it was also found that: there was no significant difference in TaTRPA1 between females and males, but there was a significant difference between newly emerged adults and mature adults. The relative expression level of TaPain in newly emerged males was significantly higher than that in females $(5.04 \pm 0.80, p<0.05)$. Similarly, the relative expression level of TaPyx in newly emerged males was significantly higher than that in females $(25.80 \pm 7.47, p<0.05)$. In addition, there was no significant difference in the expression levels of the three genes during the first, second, and third instar larvae.

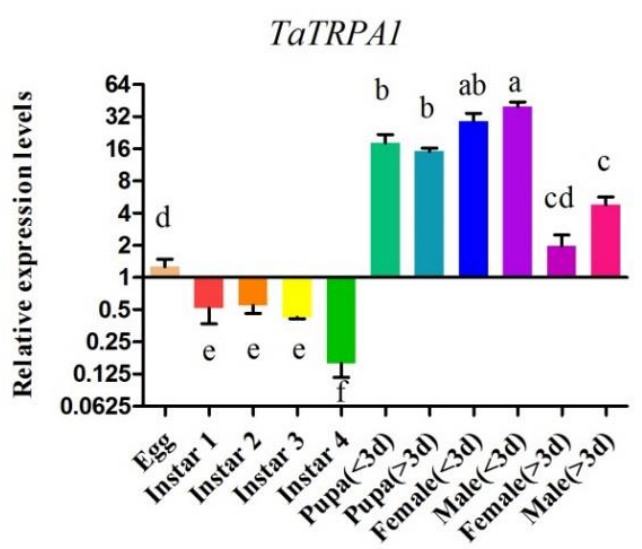

(A)

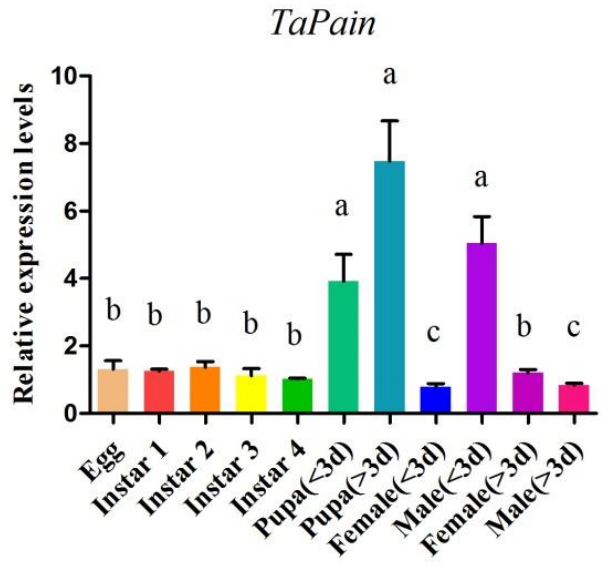

(B)

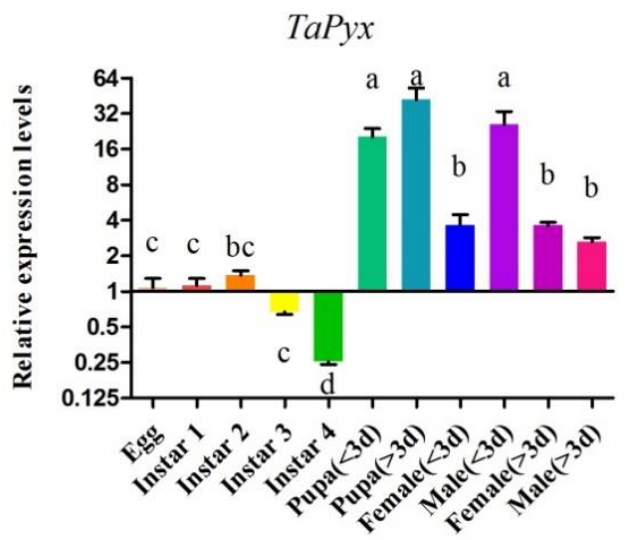

(C)

Figure 6. Relative expression levels of TaTRPA1 (A), TaPain (B), TaPyx (C) in eggs, first to fourth instars, early to late pupae, newly emerged to mature females and males. Data represent means \pm SEM. Bars with different lowercase letters are significantly different at $p<0.05$. 


\subsection{The Function of TaTRPA1, TaPain, and TaPyx Genes in Temperature Preference Behavior}

To investigate the role of TRPA in preference temperature further, T. absoluta were fed dsRNA to silence TaTRPA1, TaPain, and TaPyx gene expression, respectively. The mRNA expression after RNAi were significantly decreased compared to the control group, as shown in Figure 7. The TaTRPA1 mRNA expression level was 58.52\% lower than that in the control group (dsEGFP), and the gene expression levels of TaPain and TaPyx were decreased by $30.95 \%$ and $86.62 \%$, respectively.

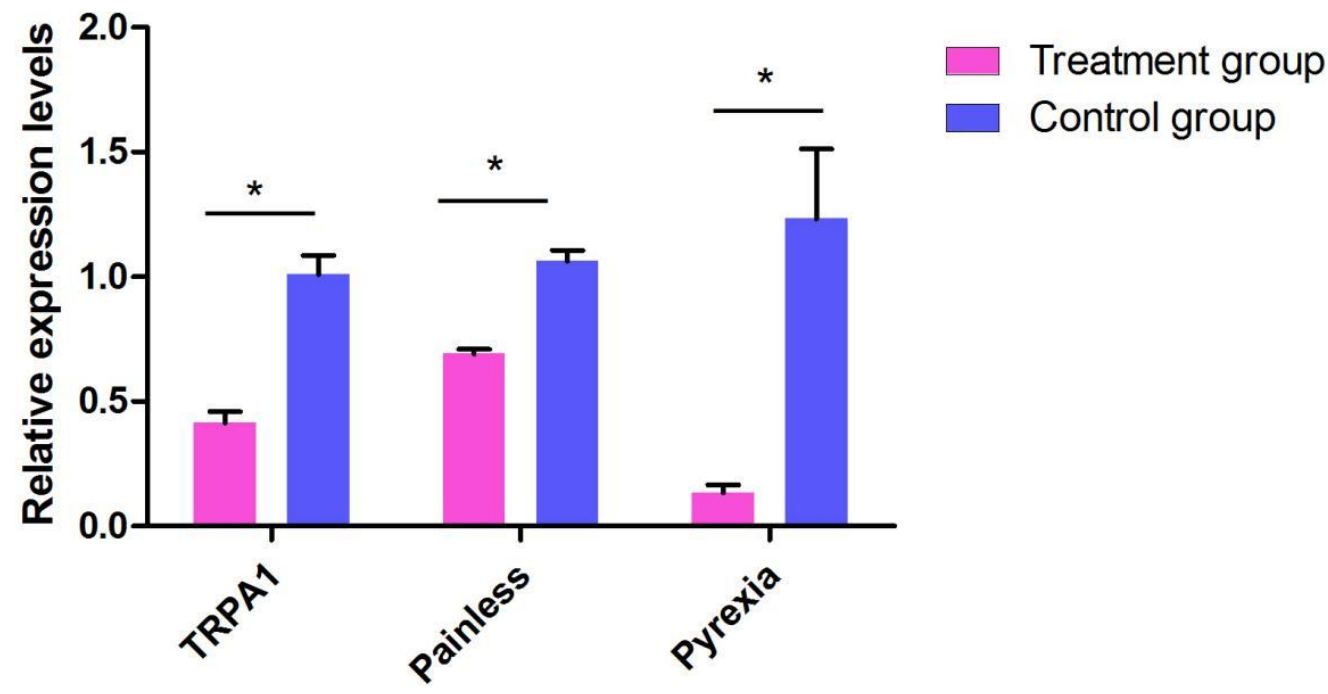

Figure 7. Effects of dsRNA treatments on mRNA expression in the Tuta absoluta. Data are presented as means \pm SEM. Data were compared by analysis of variance (ANOVA) followed by Tukey's post hoc test $\left({ }^{*} p<0.05\right)$.

We firstly tested the preference temperature of the 1 to 2 and 3 to 4 instar larvae raised in the greenhouse without any treatment, and found that their preferred temperature was $25-27^{\circ} \mathrm{C}$ (Figure 8) with the percentages of $33.1 \pm 3.4 \%$ and $41.9 \pm 3.9 \%$. On this basis, we tested the preference temperature after feeding dsTRPA1, dsPain, dsPyx, and control dsGFP (Figure 9). The experimental results showed that the preference temperature of feeding dsTRPA1, dsPain, and dsPyx was between $22.5^{\circ} \mathrm{C}$ and $24.5^{\circ} \mathrm{C}$, which was about $2{ }^{\circ} \mathrm{C}$ lower than that of the control group, with the percentages of $44.4 \pm 5.6 \%, 34.8 \pm 6.2 \%$, and $41.9 \pm 1.2 \%$, respectively, and was significantly lower than the control group. These results indicated that the preference temperature of the moth was changed after the interference of TRPA genes, and the preference temperature showed a decreasing trend.

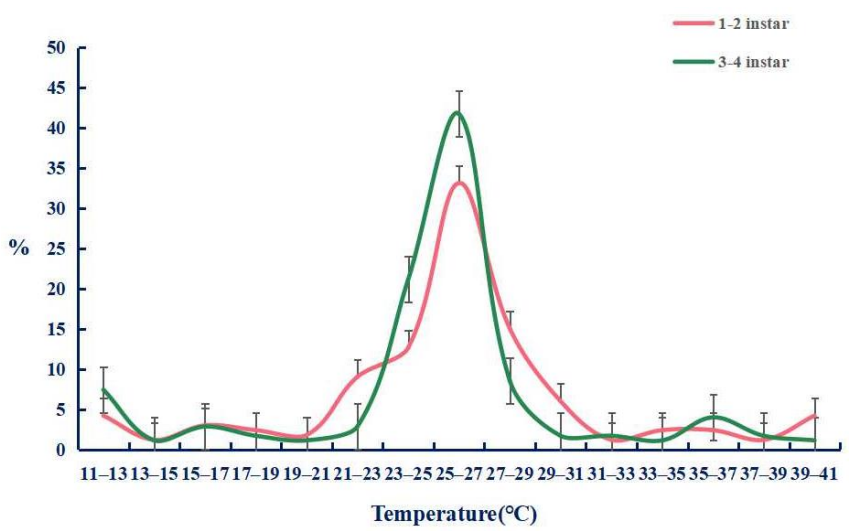

Figure 8. Temperature preference responses of Tuta absoluta larvae. The data are presented as mean $\pm \mathrm{SEM}$. 


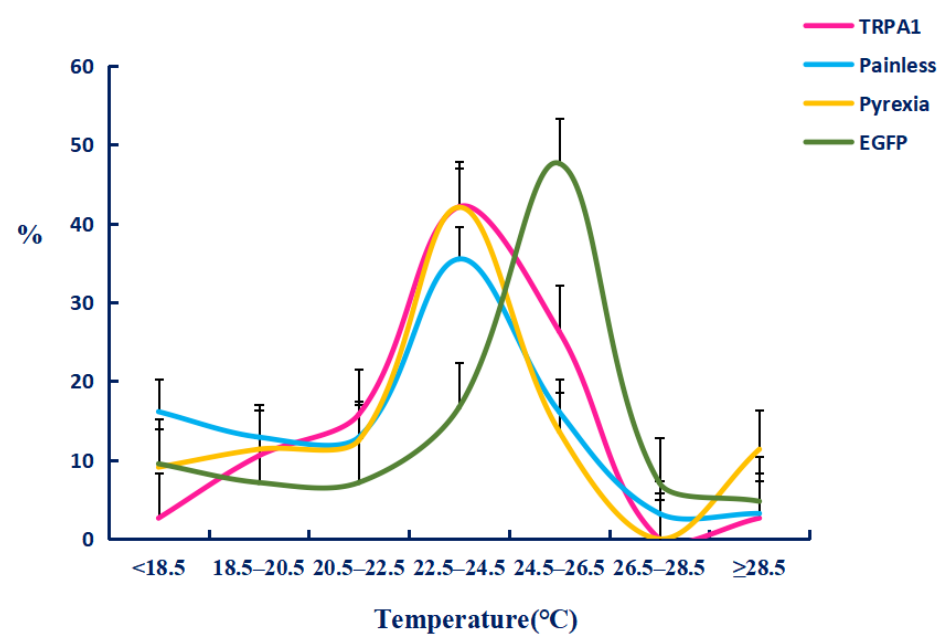

Figure 9. Temperature preference responses after dsRNA feeding in Tuta absoluta larvae. The data are presented as mean \pm SEM.

\section{Discussion}

In this study, we obtained the full-length sequence of the T. absoluta Painless gene, and bioinformatics analysis revealed that it had eight ankyrin repeats and six transmembrane domains. Ankyrin repeats are about 33 amino acids in length and have at least four contiguous copies that are involved in protein-protein interactions. Interestingly, there are eight ankyrin repeats in T. absoluta but less in other reported insects [52,54]. According to the reported genome sequence of Tribolium castaneum [54], the Painless protein of T. castaneum was found to have six ankyrin repeats by SMART analysis, and TcPain played a role in the rapid acclimation to high temperature [55]; while only two ankyrin repeats were found in the TRP study of B. tabaci, and BtTRP played a role in thermal tolerance at $35{ }^{\circ} \mathrm{C}$ [52]. It can be calculated that the number of anchors varies greatly among different species. The ankyrin repeats have been found in proteins of diverse functions such as ion transporters and signal transducers $[56,57]$. However, the role of different amounts of ankyrin repeats in temperature adaptation needs to be further studied. In addition, it was found that Pyrexia had six transmembrane domains in T. absoluta, which is consistent with the results of previous studies on the TRPA subfamily. Besides, as shown in Figure 3B, there were two regions of low complexity detected by the SEG program. The function of these regions needs to be further studied, and it was speculated that they had little influence on the function of the whole Pyrexia. In previous studies, it was believed that the TRP channel usually contains four subunits, each of which has six transmembrane proteins, and its $\mathrm{N}$-terminal and C-terminal are both intracellular [58], which is consistent with the protein prediction results of the TaPyx protein. However, studies in invertebrates have also found that the N-terminal and C-terminal of the TRP channel exist extracellular, such as the TRP channel in B. tabaci [51]. In fact, TRP is a class of nonselective cationic channel proteins that exist on the membrane of the cell membrane or intracellular organelle membrane, and the mechanism of its signal conversion in many systems needs to be further studied.

The results of the study based on the expression profile showed that there were differences in expression between females and males. Differential gene expression between the sexes leads to phenotypic differences between the sexes [59,60], which are manifested as differences in morphology, behavior, and physiology [61]. In the present study, there were also expression differences between females and males in T. absoluta, and their effects on behavior and physiology need to be further studied. In addition, the relative expression levels of TaPain and TaPyx at the initial emergence stage were significantly higher than those at the older development stage in males, which was also found in other insects such as Monochamus alternatus and Frankliniella occidentalis [62,63]. This phenomenon is common in invertebrates and may be a response to the transition from the larval stage to adult stage of insects through self-regulation to adapt to the environment. 
There are many different sensory organs that can distributed in different tissues in Drosophila [36], and they can variously express such as in this present study. The expression levels of TaTRPA1 and TaPyx were significantly lower in larvae than those in adults. Many studies showed that the cold resistance and thermal plasticity of larvae were higher than that of adults $[16,17]$. Therefore, we speculated that the larvae would be more sensitive to the selection of preference temperature, and the larvae were easy to perform the RNAi experiment, so we used larvae as the research objects.

Temperature preference is an important factor in understanding individual thermoregulation, population, or community dynamics. Here, we used the temperature preference meter to determine the preference temperature of $T$. absoluta quantitatively. In the process of recording data, dead or inactive insects were removed and not counted in the total, thus reducing experimental errors. The results of the study found that the preference temperature of T. absoluta is close to the suitable temperature for growth and development $\left(25-27^{\circ} \mathrm{C}\right)$, which is similar to wild-type D. melanogaster $\left(\sim 24{ }^{\circ} \mathrm{C}\right)$ [64]. In addition, it is consistent with the research results of Apolygus lucorum $\left(25-28{ }^{\circ} \mathrm{C}\right)$ [65]. These studies show that insects have the ability to sense and respond to temperature changes. On this basis, by interfering with TaTRPA1, TaPain, and TaPyx genes, the temperature preference behavior of T. absoluta changed, and their preference temperature showed a decreasing trend. After interfering with the three target genes, the preferred temperature became 22.5-24.5 ${ }^{\circ} \mathrm{C}$, which was $2{ }^{\circ} \mathrm{C}$ lower than the control group. The expression levels of TaPain, TaPyx, and TaTRPA1 genes were decreased to different degrees by RNAi, and the preferred temperature was changed to different degrees after interference, and the final result was two degrees lower than the optimal temperature of the control group, suggesting that these genes play a similar role in the selection of temperature preference of T. absoluta. DmTRPA1 was helpful for $D$. melanogaster larvae to choose an $18{ }^{\circ} \mathrm{C}$ environment as much as possible [66], which was lower than the suitable temperature for growth and development. Similarity, Dillon et al. reported that knocking out related genes resulted in a decrease in preference temperature in ectotherms [67]. As a temperature sensitive element, DmTRPA1 can not only sense the change rate of external temperature [68], but also regulate the physiological rhythm of D. melanogaster [69]. DmPyx can also regulate the biological clock of D. melanogaster by sensing temperature [70]. BmTRPA1 can not only make silkworms sense the temperature change and make an immediate response quickly, but also regulate the long-term adaptive diapause response related to the temperature and affect the diapause behavior of offspring [71]. The interference results showed that AgTRPA1 could regulate the preference of larvae to a higher temperature [72]. TcTRPA1, TcPain, and TcPyx also played an important role in the heat tolerance of T. castaneum. The silence of TcTRPA1 affected its escape behavior to high temperature $\left(39\right.$ and $\left.42{ }^{\circ} \mathrm{C}\right)$ [55].

\section{Materials and Methods}

\subsection{Insect Rearing and Host Plants}

The tomato leaf miner Tuta absoluta colony used in this experiment was originally collected in Yuxi, Yunnan Province, in August 2018. The tomato variety planted is Maofen. In the laboratory, the tomato leaf miner was reared in an insectary at $25 \pm 2{ }^{\circ} \mathrm{C}$ under $50-60 \%$ relative humidity with a 14:10 h light:dark cycle. The host plants were individually grown in $9-\mathrm{cm}$-diameter pots under the same conditions as the tomato leaf miner.

\subsection{RNA Extraction and cDNA Synthesis}

Total RNA was isolated using the Micro total RNA Extraction Kit (Tianmo Biotech, Beijing, China). Subsequently, a NanoPhotometerTM P330 (Implen, Munich, Germany) and $1 \%$ agarose gel electrophoresis were used to determine the RNA quality and concentration. The first-strand cDNA was generated from $1.0 \mu \mathrm{g}$ RNA using the Super Script First-Strand Synthesis System (TransGen, Beijing, China). 


\subsection{Cloning of the Three Genes of TRPA Family}

The full length cDNAs were obtained using a Taq DNA Polymerase amplification kit (TransGen, Beijing, China) according to the manufacturer's instructions. The TRPA1, Painless, and Pyrexia homologous genes of B. mori (BAO53207.1, BAO53208.1, and NP_001296536.1) and D. melanogaster (NP_001261602.1, NP_001261176.1, and NP_612015.1) were used to query the transcriptome dataset of T. absoluta by blastp and tblastn. According to the corresponding sequences of T. absoluta, primers were designed by primer 5.0 (Table 1). The amplified fragments were purified using an AxyPrep TM DNA Gel Extraction Kit (Axygen, West Orange, NJ, USA). Finally, the distinct single-band amplification products were cloned into the pEASY-T3 vector (Transgen) and sequenced.

Table 1. Primers used for cDNA cloning, quantitative real-time PCR (qPCR), double-stranded RNA (dsRNA) synthesis.

\begin{tabular}{|c|c|c|c|}
\hline Gene Name & Primer Name & Primer Sequence $\left(5^{\prime} \rightarrow 3^{\prime}\right)$ & Amplicon Length/bp \\
\hline \multicolumn{4}{|c|}{ Primers for full-length gene amplification } \\
\hline \multirow{2}{*}{ TRPA1 } & TRPA1-F277 & GCGGTGGAGTTGTGCTT & \multirow{2}{*}{515} \\
\hline & TRPA1-R791 & CGGCTGGCGTAATGTAG & \\
\hline \multirow{6}{*}{ Painless } & Pain-F139 & AGTGCTTGTGGACAGTGTT & \multirow{2}{*}{1488} \\
\hline & Pain-R1626 & CTAGCGAGTTATTTGGGTAA & \\
\hline & Pain-F1456 & GCGTCGGACTACGAAATA & \multirow{2}{*}{1314} \\
\hline & Pain-R2769 & GCAGAAAGTGAGGAAACAA & \\
\hline & Pain-F2546 & ACAAGAGATAAGAGCGGATG & \multirow{2}{*}{727} \\
\hline & Pain-F3272 & GTGGAAGGCAGTTAGAAGTA & \\
\hline \multirow[t]{4}{*}{ Pyrexia } & Pyx-F1 & CGAGGTGCTTCAGTTCA & \multirow{2}{*}{1250} \\
\hline & Pyx-R1250 & CTCACGATTACAAACCATTC & \\
\hline & Pyx-F867 & AGTGCTTTTACATCCG & \multirow{2}{*}{1460} \\
\hline & Pyx- R2326 & GACATCAACAATAGGGT & \\
\hline & & Primers for $\mathrm{qPCR}$ & \\
\hline \multirow{4}{*}{ TRPA1 } & TRPA1-QF123 & ACACGAAGCAGCCAAAAACG & \multirow{2}{*}{183 (for RNAi) } \\
\hline & TRPA1-QR305 & GCTCCGGACCTCAAGCACAA & \\
\hline & TRPA1-QF675 & AGGAGGGAGGTTGGAAGAC & \multirow{2}{*}{115 (for expression) } \\
\hline & TRPA1-QR789 & GCTGGCGTAATGTAGAGGC & \\
\hline \multirow{2}{*}{ Painless } & Pain-QF2749 & GTTTGTTTCCTCACTTTCTGCC & \multirow{2}{*}{132} \\
\hline & Pain-QR2880 & ATCCACCGCCTTCTATATCCTC & \\
\hline \multirow{2}{*}{ Pyrexia } & Pyx-QF1821 & TTCTTCTGCССTTGTCTCACC & \multirow{2}{*}{135} \\
\hline & Pyx-QR1955 & CCGTATTGTTTCCGCATTTTG & \\
\hline \multirow{2}{*}{ RpL5 } & RpL5-QF & CAGTCGTCGAGCCAGCAACA & \multirow{2}{*}{$129 \mathrm{bp}$} \\
\hline & RpL5-QR & TCCCGCATTGAAGGAGACCA & \\
\hline \multirow{3}{*}{ TRPA1 } & & Primers for dsRNA synthesis & \\
\hline & TRPA1-DF277 & taatacgactcactatagggGCGGTGGAGTTGTGCTT & \multirow{2}{*}{515} \\
\hline & TRPA1-DR791 & taatacgactcactatagggCGGCTGGCGTAATGTAG & \\
\hline \multirow{2}{*}{ Painless } & Pain-DF1456 & taatacgactcactatagggGCGTCGGACTACGAAATA & \multirow{2}{*}{303} \\
\hline & Pain-DR1758 & taatacgactcactatagggTCAGAAGTGGTCGCAAAT & \\
\hline \multirow{2}{*}{ Pyrexia } & Pyx-DF1281 & taatacgactcactatagggCATCACGTACACATGGCAAAA & \multirow{2}{*}{335} \\
\hline & Pyx-DR1615 & taatacgactcactatagggAGAACTCAAGTAAAACGGGGG & \\
\hline
\end{tabular}




\subsection{Sequence Analysis of the Three TRPA Genes}

Sequence alignment and identity analyses were performed using DNAMAN (version 5.0; LynnonBioSoft, QC, Canada). Molecular weights and pIs were calculated using ExPASy (http://web.expasy.org/protparam/. Accessed on 20 April 2021). Conserved functional domains of the deduced protein sequences of the three genes were identified using SMART software (http:/ / smart.embl-heidelberg.de/. Accessed on 20 April 2021). Crossmembrane domains was predicted using TMHMM Server v. 2.0 (http:/ / www.cbs. dtu.dk/services/TMHMM/. Accessed on 20 April 2021). Multiple protein sequences were aligned using DNAMAN and implemented in the MAGE 7.0 software package to evaluate the molecular evolutionary relationships between TRPA1, Painless and Pyrexia genes, and various insects. The amino acid sequences of TRPA1, Painless, and Pyrexia of different insects were downloaded from NCBI (https: / / www.ncbi.nlm.nih.gov / . Accessed on 1 May 2021) to construct the phylogenetic tree. The phylogenetic tree was constructed with the maximum likelihood method using MAGE 7.0 software. Bootstrap majority consensus values for 1000 replicates are indicated at each branch point (\%).

\subsection{Quantitative Real-Time PCR Analysis of Relative Expression Levels}

The expression profiles in different development stages and the effect of gene silencing after feeding dsRNA in T. absoluta were assessed. The different development stages included eggs, nymphs from the first to fourth instars, early to late pupae, newly emerged to mature females and males. The relative mRNA expression level was analyzed by reverse transcription real-time polymerase chain reaction. The primer sequences used are listed in Table 1. The reactions were performed using an ABI 7500 Real-time PCR system (Applied Biosystems, Waltham, MA, USA). All amplifications were confirmed by sequencing, and the specificity of RT-qPCR reactions was estimated by melting curve analysis. PCR assays were prepared to a final volume of $20.0 \mu \mathrm{L}$ with $1.0 \mu \mathrm{L}$ of the cDNA template, $10.0 \mu \mathrm{L}$ of $2 \times$ TransStart TM Green qPCR SuperMix (Transgen), $200 \mu \mathrm{M}$ of each gene-specific primer (Table 1), and $0.4 \mu \mathrm{L}$ of Passive Reference Dye (Transgen). A thermocycler was programmed with the following cycling conditions: (1) $94{ }^{\circ} \mathrm{C}$ for $1 \mathrm{~min}$, followed by (2) 40 cycles of $95{ }^{\circ} \mathrm{C}$ for $15 \mathrm{~s}, 61^{\circ} \mathrm{C}$ for $30 \mathrm{~s}$, and $72{ }^{\circ} \mathrm{C}$ for $30 \mathrm{~s}$. There were three repetitions for each treatment or control, with 4 larvae in each repetition, and each repetition was assessed in triplicate (technical replicates). RpL5 (large subunit 5 ribosomal protein) was used as the reference gene. Amplification efficiency was validated by constructing a standard curve using seven serial dilutions of cDNA. The relative quantification of mRNA expression was calculated using the mathematical model of (Livak and Schmittgen 2001; Pfaffl 2001) [73,74], which simplifies to $2^{-\Delta \Delta C T}$ as follows: $(\Delta \Delta \mathrm{CT}=(\mathrm{Ct}$ target $-\mathrm{Ct}$ reference $)$ treatment $-(\mathrm{Ct}$ target - Ct reference) control).

\subsection{Production of dsRNA Transcription Templates and Synthesis of dsRNA}

To generate dsRNA, three fragment templates of TRPA1, Painless, and Pyrexia were amplified by PCR using CDNAs cloned previously as templates with forward and reverse primers containing the T7 primer sequence (Table 1 ) at the $5^{\prime}$ ends, respectively. Amplification reactions were conducted in $25 \mu \mathrm{L}$ containing $19.0 \mu \mathrm{L}$ of $\mathrm{ddH}_{2} \mathrm{O}, 2.5 \mu \mathrm{L}$ of $10 \times$ buffer, $0.5 \mu \mathrm{L}$ of dNTPs (10 mM for each nucleotide), $1.0 \mathrm{~mL}$ of forward primer $(10 \mathrm{mM} / \mu \mathrm{L})$, $1.0 \mathrm{~mL}$ of reverse primer $(10 \mathrm{mM} / \mu \mathrm{L}), 0.5 \mu \mathrm{L}$ of cDNA template, and $0.5 \mu \mathrm{L}$ of Taq DNA Polymerase (5 U $\mu \mathrm{L}^{-1}$; TransStart). The PCR cycling conditions were as follows: $94{ }^{\circ} \mathrm{C}$ for $5 \mathrm{~min}$, followed by 35 cycles of $94{ }^{\circ} \mathrm{C}$ for $30 \mathrm{~s}, 60{ }^{\circ} \mathrm{C}$ for $30 \mathrm{~s}$, and $72{ }^{\circ} \mathrm{C}$ for $30 \mathrm{~s}$, and a final extension step of $72{ }^{\circ} \mathrm{C}$ for $10 \mathrm{~min}$. The amplification of PCR products was confirmed by separation on $1.5 \%$ agarose gels and visualized by staining with ethidium bromide under UV light. The sequences were verified by sequencing of Sangon Biotech. dsRNA was synthesized using the MEGAscript RNAi Kit (Ambion, Austin, TX, USA), and $1 \mu \mathrm{g}$ of PCR product was used as the transcription template. dsRNA was resuspended in RNasefree water. dsRNA was analyzed by agarose gel electrophoresis and quantified spectrophotometrically. The dsRNA was stored at $-80{ }^{\circ} \mathrm{C}$ prior to further use. 


\subsection{RNA Interference (RNAi) and Detection}

In this experiment, double-stranded RNA was delivered to T. absoluta larvae via feeding. Detached leaflets from Maofen tomatoes had their petioles immersed in $200 \mu \mathrm{L}$ of water containing either $5 \mu \mathrm{g}$ of dsRNA from each target gene or a GFP control, in triplicate. Uptake of the dsRNA solution by the tomato leaflets took 3-4 h. Immediately after uptake, second instar larvae $(n=15)$ were gently placed onto leaflets for feeding, and individuals were sampled $48 \mathrm{~h}$ after initiation of feeding. Controls with dsRNA from the GFP gene sequence were run in parallel. The effects of RNAi on the larvae were evaluated by comparative quantification real-time PCR of each target gene compared to the control.

\subsection{Preference Temperature Behavioral Assay}

A temperature preference tester was used to test the preference temperature of the tomato leaf miner. By using the semiconductor refrigeration chip as the temperature control unit, the temperature can be quickly and accurately controlled. The tester has a flat plate $(30 \mathrm{~cm} \times 10 \mathrm{~cm} \times 1 \mathrm{~cm})$ capable of generating a range of temperature gradients. The flat plate in the test area is $0.72{ }^{\circ} \mathrm{C} / \mathrm{cm}$. There is a $0.4 \mathrm{~cm}$ high plexiglass cover above the plate to prevent the larvae from escaping and to ensure that they can move freely on the temperature plate [28]. In each experiment, $15 \mathrm{~s}$ instar larvae were placed in the temperature range of $16-30{ }^{\circ} \mathrm{C}$ and allowed to move for $20 \mathrm{~min}$ under dark conditions [75], taking pictures every $10 \mathrm{~min}$ to observe and record the distribution of T. absoluta on the temperature plate. By observing and counting the number of larvae staying in different temperature zones, the percentage of the number of larvae in the temperature zone was finally calculated. These percentages represent the degree to which T. absoluta prefers the temperature. Each treatment had 4 biological replicates.

\subsection{Statistical Analysis}

Statistical analyses were carried out using the GraphPad Prism 5.0 (GraphPad, San Diego, CA, USA). The target gene expression profile was analyzed using one-way analysis of variance (ANOVA), followed by Tukey's multiple comparison test. The RNA interference efficiency and the repressed gene expression level was analyzed by $t$ test. Data are presented as mean \pm standard error (mean $\pm \mathrm{SEM}$ ). Differences were considered significant when $p<0.05$. The temperature preference behavior after RNAi was calculated by the percentage of larvae in the total number in each temperature zone.

\section{Conclusions}

In summary, the present study firstly indicated the molecular characterization of TaPain and TaPyx in T. absoluta, and the mRNA expression profile of TaTRPA1, TaPain, and TaPyx during different developmental stages. The results of feeding TaTRPA1, TaPain, and TaPyx dsRNA showed that the three target genes were key elements in temperature perception and played a key role in preference temperature. Our data improve our understanding of the mechanism of temperature sensation at the molecular level in T. absoluta, and provide some basis for the study of other Lepidoptera insects' temperature preference. Moreover, it is of great significance in enriching the research progress of "thermos TRP".

Author Contributions: X.-D.W. did most of the experiments and analyzed the results and wrote the paper; Z.-K.L. did the bioinformatic analysis and revised the references; S.-X.J. did part of the RNAi experiment and the bioinformatic analysis; S.-Y.B. did the expression profiles experiment of different development stages; W.-X.L. helped to revise the introduction and results; G.-F.Z. helped to analyze the results; F.-H.W. helped to revise the discussion; Z.-C.L. was responsible for the experiment design and the manuscript's revision. All authors have read and agreed to the published version of the manuscript.

Funding: This research was funded by the National Natural Science Foundation of China (32072494 and 31672088) and the National Key Research and Development Program (2017YFC1200600).

Institutional Review Board Statement: Not applicable. 
Informed Consent Statement: Not applicable.

Conflicts of Interest: The authors declare no conflict of interest.

\section{References}

1. Garcia, M.F.; Espul, J.C. Bioecology of the tomato moth (Scrobipalpula absoluta) in Mendoza, Argentine Republic. Rev. Investig. Agrop. 1982, 17, 135-146.

2. $\quad$ Desneux, N.; Wajnberg, E.; Wyckhuys, K.A.G.; Burgio, G.; Arpaia, S.; Narváez-Vasquez, C.A.; González-Cabrera, J.; Ruescas, D.C.; Tabone, E.; Frandon, J.; et al. Biological invasion of European tomato crops by Tuta absoluta: Ecology, geographic expansion and prospects for biological control. J. Pest Sci. 2010, 83, 197-215. [CrossRef]

3. Brévault, T.; Sylla, S.; Diatte, M.; Bernadas, G.; Diarra, K. Tuta absoluta Meyrick (Lepidoptera: Gelechiidae): A New Threat to Tomato Production in Sub-Saharan Africa. Afr. Entomol. 2014, 22, 441-444. [CrossRef]

4. Chen, L.M.; Li, X.W.; He, T.J.; Li, P.J.; Liu, Y.; Zhou, S.X.; Wu, Q.C.; Chen, T.T.; Lu, Y.B.; Hou, Y.M. Comparative biochemical and transcriptome analyses in tomato and eggplant reveal their differential responses to Tuta absoluta infestation. Genomics 2021, 113, 2108-2121. [CrossRef] [PubMed]

5. Zhang, G.F.; Ma, D.Y.; Wang, Y.S.H.; Gao, Y.H.; Liu, W.X.; Zhang, R.; Fu, W.J.; Xian, X.Q.; Wang, J.; Kuang, M.; et al. First report of the South American tomato leafminer, Tuta absoluta (Meyrick), in China. J. Integr. Agr. 2020, 19, 1912-1917. [CrossRef]

6. Zhang, G.F.; Liu, W.X.; Wan, F.H.; Xian, X.Q.; Zhang, Y.B.; Guo, J.Y. Bioecology, damage and management of the tomato leafminer Tuta absoluta (Meyrick) (Lepidoptera: Gelechiidae) a world wide quarantine pest. J. Biosaf. 2018, 27, 155-163.

7. Biondi, A.; Guedes, R.N.C.; Wan, F.H.; Desneux, N. Ecology, worldwide spread, and management of the invasive South American tomato pinworm, Tuta absoluta: Past, present, and future. Ann. Rev. Entom. 2017, 63, 239-258. [CrossRef] [PubMed]

8. Desneux, N.; Luna, M.G.; Guillemaud, T.; Urbaneja, A. The invasive South American tomato pinworm, Tuta absoluta, continues to spread in Afro-Eurasia and beyond: The new threat to tomato world production. J. Pest Sci. 2011, 84, 403-408. [CrossRef]

9. Campos, M.R.; Biondi, A.; Adiga, A.; Guedes, R.N.C.; Desneux, N. From the Western Palaearctic region to beyond: Tuta absoluta ten years after invading Europe. J. Pest Sci. 2017, 90, 787-796. [CrossRef]

10. Mansour, R.; Brévault, T.; Chailleux, A.; Cherif, A.; Grissa-Lebdi, K.; Haddi, K.; Mohamed, S.A.; Nofemela, R.S.; Oke, A.; Sylla, S.; et al. Occurrence, biology, natural enemies and management of Tuta absoluta in Africa. Entom. Gen. 2018, 38, 83-111. [CrossRef]

11. Gray, E.M. Thermal acclimation in a complex life cycle: The effects of larval and adult thermal conditions on metabolic rate and heat resistance in Culex pipiens (Diptera: Culicidae). J. Insect Physiol. 2013, 59, 1001-1007. [CrossRef]

12. Overgaard, J.; Sørensen, J.G. Rapid thermal adaptation during field temperature variations in Drosophila melanogaster. Cryobiology 2008, 56, 159-162. [CrossRef]

13. Bowler, K.; Terblanche, J.S. Insect thermal tolerance: What is the role of ontogeny, ageing and senescence. Biol. Rev. 2008, 83, 339-355. [CrossRef]

14. Klepsatel, P.; Girish, T.N.; Dircksen, H.; Gáliková, M. Reproductive fitness of Drosophila is maximised by optimal developmental temperature. J. Exp. Biol. 2019, 222, jeb202184. [CrossRef] [PubMed]

15. Li, D.; Li, X.W.; Ma, L.; Fu, K.Y.; Ding, X.H.; Guo, W.C.; Lü, Y.B. Effects of temperature on the growth, development and reproduction of the tomato leaf miner, Tuta absoluta (Lepidoptera: Gelechiidae). Acta Entomol. Sin. 2019, 62, $1417-1426$.

16. Tarusikirwa, V.L.; Mutamiswa, R.; Chidawanyika, F.; Nyamukondiwa, C. Cold hardiness of the South American tomato pinworm Tuta absoluta (Lepidoptera: Gelechiidae): Both larvae and adults are chill-usceptible. Pest Manag. Sci. 2020, 77, 184-193. [CrossRef]

17. Tarusikirwa, V.L.; Mutamiswa, R.; English, S.; Chidawanyika, F.; Nyamukondiwa, C. Thermal plasticity in the invasive south American tomato pinworm Tuta absoluta (Meyrick) (Lepidoptera: Gelechiidae). J. Ther. Biol. 2020, 90, 102598. [CrossRef] [PubMed]

18. Fry, F.E.J. Effects of the environment on animal activity. Univ. Toronto Stud. Biol. 1947, 55, 1-62.

19. Huey, R.B.; Stevenson, R.D. Integrating thermal physiology and ecology of ectotherms: A discussion of approaches. Am. Zool. 1979, 19, 357-366. [CrossRef]

20. Huey, R.B. Temperature, physiology, and the ecology of reptiles. In Biology of the Reptilia; Academic Press: New York, NY, USA, 1982; Volume 12, pp. 25-74.

21. Hochachka, P.W.; Somero, G.N. Biochemical Adaptation, Mechanisms and Processes in Physiological Evolution; Oxford University Press: New York, NY, USA, 2002.

22. Johnson, J.A.; Kelsch, S.W. Effects of evolutionary thermal environment on temperature-preference relationships in fishes. Environ. Biol. Fish. 1998, 53, 447-458. [CrossRef]

23. Martin, T.L.; Huey, R.B. Why "suboptimal" is optimal: Jensen's inequality and ecotherm thermal preferences. Am. Nat. 2008, 171, E102-E118. [CrossRef]

24. Clusella-Trullas, S.; Blackburn, T.M.; Chown, S.L. Climatic predictors of temperature performance curve parameters in ectotherms imply complex responses to climate change. Am. Nat. 2011, 177, 738-751. [CrossRef]

25. William, W.R.; Martha, E.C. Behavioral Thermoregulation and the "Final Preferendum" Paradigm. Am. Zool. 1979, 19, $211-224$.

26. Hagstrum, D.W.; Flinn, P.W.; Gaffney, J.J. Temperature gradient on Tribolium castaneum (Coleoptera: Tenebrionidae) adult dispersal in stored wheat. Environ. Entomol. 1998, 1, 123-129. [CrossRef]

27. Fedorka, K.M.; Kutch, I.C.; Collins, L.; Musto, E. Cold temperature preference in bacterially infected Drosophila melanogaster improves survival but is remarkably suboptimal. J. Insect Physol. 2016, 93-94, 36-41. [CrossRef] [PubMed] 
28. Ji, S.X.; Wang, X.D.; Shen, X.N.; Liang, L.; Liu, W.X.; Wan, F.H.; Lü, Z.C. Using RNA Interference to Reveal the Function of Chromatin Remodeling Factor ISWI in Temperature Tolerance in Bemisia tabaci Middle East-Asia Minor 1 Cryptic Species. Insects 2020, 11, 113. [CrossRef] [PubMed]

29. Crickenberger, S.; Hui, T.Y.; Yuan, F.L.; Bonebrake, T.C.; Williams, G.A. Preferred temperature of intertidal ectotherms: Broad patterns and methodological approaches. J. Therm. Biol. 2020, 87, 102468. [CrossRef]

30. Buckley, L.B. Linking traits to energetics and population dynamics to predict lizard ranges in changing environments. Am. Nat. 2008, 171, E1-E19. [CrossRef]

31. Buckley, L.B.; Urban, M.C.; Angilletta, M.J.; Crozier, L.G.; Rissler, L.J.; Sears, M.W. Can mechanism inform species' distribution models? Ecol. Lett. 2010, 13, 1041-1054. [CrossRef]

32. Monaco, C.J.; Wethey, D.S.; Gulledge, S.; Helmuth, B. Shore-level size gradients and thermal refuge use in the predatory sea star Pisaster ochraceus: The role of environmental stressors. Mar. Ecol. Prog. Ser. 2015, 539, 191-205. [CrossRef]

33. Huey, R.B.; Slatkin, M. Cost and benefits of lizard thermoregulation. Q. Rev. Biol. 1976, 51, 363-384. [CrossRef] [PubMed]

34. Hughes, N.F.; Grand, T.C. Physiological ecology meets the ideal-free distribution: Prediction the distribution of size-structured fish populations across temperature gradients. Environ. Biol. Fishes 2000, 59, 285-298. [CrossRef]

35. Lampert, W.; McCauley, E.; Manly, B.F.J. Trade-offs in the vertical distribution of zooplankton: Ideal free distribution with costs? Proc. R. Soc. Lond. Ser. B Biol. Sci. 2003, 270, 765-773. [CrossRef]

36. Fowler, M.A.; Montell, C. Drosophila TRP channels and animal behavior. Life Sci. 2012, 92, 394-403. [CrossRef] [PubMed]

37. Rogers, K. Transient Receptor Potential Channel. EB. 15 November 2018. Available online: https://www.britannica.com/science/ transient-receptor-potential-channel (accessed on 30 June 2021).

38. Ramsey, I.S.; Delling, M.; Clapham, D.E. An introduction to TRP channels. Annu. Rev. Physiol. 2006, 68, 619-647. [CrossRef]

39. Venkatachalam, K.; Montell, C. TRP channels. Annu. Rev. Biochem. 2007, 76, 387-417. [CrossRef]

40. Montell, C. The TRP superfamily of cation channels. Sci. Signal. 2005, 272, re3. [CrossRef]

41. Montell, C.; Birnbaumer, L.; Flockerzi, V.; Bindels, R.J.; Bruford, E.A.; Caterina, M.J.; Clapham, D.E.; Harteneck, C.; Heller, S.; Julius, D.; et al. A unified nomenclature for the superfamily of TRP cation channels. Mol. Cell 2002, 9, 229-231. [CrossRef]

42. Caterina, M.J.; Schumacher, M.A.; Tominaga, M.; Rosen, T.A.; Levine, J.D.; Julius, D. The capsaicin receptor: A heat-activated ion channel in the pain pathway. Nature 1997, 389, 816-824. [CrossRef]

43. Lee, Y.; Lee, J.; Bang, S.; Hyun, S.; Kang, J.; Hong, S.T.; Bae, E.; Kaang, B.K.; Kim, J. Pyrexia is a new thermal transient receptor potential channel endowing tolerance to high temperatures in Drosophila melanogaster. Nat. Genet. 2005, 37, 305-310. [CrossRef]

44. Neely, G.G.; Keene, A.C.; Duchek, P.; Chang, E.C.; Wang, Q.P.; Aksoy, Y.A.; Rosenzweig, M.; Costigan, M.; Woolf, C.J.; Garrity, P.A.; et al. TrpA1 regulates thermal nociception in Drosophila. PLoS ONE 2011, 6, e24343. [CrossRef]

45. Tracey, W.D.; Wilson, R.I.; Laurent, G.; Benzer, S. painless, a Drosophila gene essential for nociception. Cell 2003, 113, 261-273. [CrossRef]

46. Hwang, R.Y.; Stearns, N.A.; Tracey, W.D. The ankyrin repeat domain of the TRPA protein Painless is important for thermal nociception but not mechanical nociception. PLoS ONE 2012, 7, e30090. [CrossRef] [PubMed]

47. Zhong, L.; Bellemer, A.; Yan, H.; Ken, H.; Jessica, R.; Hwang, R.Y.; Pitt, G.S.; Tracey, W.D. Thermosensory and non-thermosensory isoforms of Drosophila melanogaster TRPA1 reveal heat sensor domains of a thermoTRP channel. Cell Rep. 2012, 1, 43-55. [CrossRef]

48. Sokabe, T.; Tsujiuchi, S.; Kadowaki, T.; Tominaga, M. Drosophila Painless is a $\mathrm{Ca}^{2+}$-requiring channel activated by noxious heat. J. Neurosci. 2008, 28, 9929-9938. [CrossRef] [PubMed]

49. Patapoutian, A. TRP channels and thermosensation. Chem. Senses 2005, 30, i193-i194. [CrossRef] [PubMed]

50. Castillo, K.; Diaz-Franulic, I.; Canan, J.; Gonzalez-Nilo, F.; Latorre, R. Thermally activated TRP channels: Molecular sensors for temperature detection. Phys. Biol. 2018, 15, 021001. [CrossRef]

51. Lü, Z.C.; Li, Q.; Liu, W.X.; Wan, F.H. Transient Receptor Potential Is Essential for High Temperature Tolerance in Invasive Bemisia tabaci Middle East Asia Minor 1 Cryptic Species. PLoS ONE 2014, 9, e108428. [CrossRef]

52. Ji, S.X.; Shen, X.N.; Liang, L.; Wang, X.D.; Liu, W.X.; Wan, F.H.; Lü, Z.C. Molecular characteristics and temperature tolerance function of the transient receptor potential in the native Bemisia tabaci AsiaII3 cryptic species. J. Integ. Agr. 2020, 19, $2746-2757$. [CrossRef]

53. Dai, T.M.; Wang, Y.S.; Liu, W.X.; Lü, Z.C.; Wan, F.H. Thermal discrimination and transgenerational temperature response in Bemisia tabaci Mediterranean (Hemiptera: Aleyrodidae): Putative involvement of the thermo-sensitive receptor BtTRPA. Environ. Entomol. 2018, 47, 204-209. [CrossRef] [PubMed]

54. Tribolium Genome Sequencing Consortium; Richards, S. The genome of the model beetle and pest Tribolium castaneum. Nature 2008, 452, 949-955.

55. Kim, H.G.; Margolies, D.; Park, Y. The roles of thermal transient receptor potential channels in thermotactic behavior and in thermal acclimation in the red flour beetle, Tribolium castaneum. J. Insect Physiol. 2015, 76, 47-55. [CrossRef]

56. Vo, M.N.; Terrey, M.; Lee, J.W.; Roy, B.; Moresco, J.J.; Sun, L.; Fu, H.; Liu, Q.; Weber, T.G.; Yates, J.R., 3rd; et al. ANKRD16 prevents neuron loss caused by an editing-defective tRNA synthetase. Nature 2018, 557, 510-515. [CrossRef] [PubMed]

57. Bork, P. Hundreds of ankyrin-like repeats in functionally diverse proteins: Mobile modules that cross phyla horizontally? Proteins 1993, 17, 363-374. [CrossRef] [PubMed]

58. Fan, X.X.; Yang, L.; Xiang, B. Recent Research Progress of $\mathrm{Ca}^{2+}$ Permeable Channels. Prog. Biochem. Biophys. 2016, 43, 1129-1138. 
59. 59. Bubb, K.J.; Wen, H.; Panayiotou, C.M.; Finsterbusch, M.; Khan, F.J.; Chan, M.V.; Priestley, J.V.; Baker, M.D.; Ahluwalia, A. Activation of neuronal transient receptor potential vanilloid 1 channel underlies 20-hydroxyeicosatetraenoic acid-induced vasoactivity: Role for protein kinase A. Hypertension 2013, 62, 426-433. [CrossRef]

60. Su, H.A.; Bai, X.; Zeng, T.; Lu, Y.Y.; Qi, Y.X. Identification, characterization and expression analysis of transient receptor potential channel genes in the oriental fruit fly. Bactrocera dorsalis. BMC Genom. 2018, 19, 674. [CrossRef]

61. Bain, S.A.; Marshall, H.; de la Filia, A.G.; Laetsch, D.R.; Husnik, F.; Ross, L. Sex-specific expression and DNA methylation in a species with extreme sexual dimorphism and paternal genome elimination. Mol. Ecol. 2021, 1-17. [CrossRef]

62. Chen, J.X.; Chen, J.; Lin, T. Identification and expression of dynamin-1-like protein gene from Monochamus alternatus. Jiangsu J. Agric. Sci. 2017, 33, 524-532.

63. Zhang, Z.K.; Wu, S.Y.; Lei, Z.R. Cloning, Sequence Analysis and Expression Profile of an Odorant Binding Protein Gene in Western Flower Thrips (Frankliniella occidentalis). Sci. Agric. Sin. 2016, 49, 1106-1116.

64. Sayeed, O.; Benzer, S. Behavioral genetics of thermosensation and hygrosensation in Drosophila. Proc. Natl. Acad. Sci. USA 1996, 93, 6079-6084. [CrossRef] [PubMed]

65. Fu, T.; Hull, J.J.; Yang, T.; Wang, G. Identification and functional characterization of four transient receptor potential ankyrin 1 variants in Apolygus lucorum (Meyer-Dür). Insect Mol. Biol. 2016, 25, 370-384. [CrossRef] [PubMed]

66. Kwon, Y.; Shim, H.S.; Wang, X.; Montell, C. Control of thermotactic behavior via coupling of a TRP channel to a phospholipase C signaling cascade. Nat. Neurosci. 2008, 11, 871-873. [CrossRef] [PubMed]

67. Dillon, M.E.; Liu, R.; Wang, G.; Huey, R.B. Disentangling thermal preference and the thermal dependence of movement in ectotherms. J. Therm. Biol. 2012, 37, 631-639. [CrossRef]

68. Luo, J.; Shen, W.L.; Montell, C. TRPA1 mediates sensation of the rate of temperature change in Drosophila larvae. Nat. Neurosci. 2017, 20, 34-41. [CrossRef]

69. Lee, Y. Contribution of Drosophila TRPA1-expressing neurons to circadian locomotor activity patterns. PLoS ONE 2013, 8, e85189. [CrossRef]

70. Wolfgang, W.; Simoni, A.; Gentile, C.; Stanewsky, R. The Pyrexia transient receptor potential channel mediates circadian clock synchronization to low temperature cycles in Drosophila melanogaster. Proc. Biol. Sci. 2013, 280, 20130959. [CrossRef]

71. Sato, A.; Sokabe, T.; Kashio, M.; Yasukochi, Y.; Tominaga, M.; Shiomi, K. Embryonic thermosensitive TRPA1 determines transgenerational diapause phenotype of the silkworm, Bombyx mori. Proc. Natl. Acad. Sci. USA 2014, 111, E1249-E1255. [CrossRef] [PubMed]

72. Liu, C.; Zwiebel, L.J. Molecular characterization of larval peripheral thermosensory responses of the malaria vector mosquito Anopheles gambiae. PLoS ONE 2013, 8, e72595. [CrossRef]

73. Livak, K.J.; Schmittgen, T.D. Analysis of relative gene expression data using real-time quantitative PCR and the $2^{-\Delta \Delta C T}$ method. Methods 2001, 25, 402-408. [CrossRef]

74. Pfaffl, M.W. A new mathematical model for relative quantification in real-time RT-PCR. Nucleic Acids Res. 2001, 29, e45. [CrossRef] [PubMed]

75. Head, L.M.; Tang, X.; Hayley, S.E.; Goda, T.; Umezaki, Y.; Chang, E.C.; Leslie, J.R.; Fujiwara, M.; Garrity, P.A.; Hamada, F.N. The influence of light on temperature preference in Drosophila. Curr. Biol. 2015, 25, 1063-1068. [CrossRef] [PubMed] 